\title{
Orthotopic Homotransplantation of the Human Liver
}

\author{
Thomas E. Starzl, Ph.D., M.D., Carl G. Groth, M.D., \\ Lawrence Brettschneider, M.D., Israel Penn, M.D., \\ Vincent A. Fulginiti, M.D., John B. Moon, M.D., \\ Herve Blanchard, M.D., Alfred J. Martin, Jr., M.D., \\ Ken A. Porter, M.D. \\ From the Departments of Surgery and Pediatrics, University of Colorado School of Medicine and \\ Veterans Administration Hospital, Denver, Colorado; and the Department of Pathology, \\ St. Mary's Hospital and Medical School, London, England
}

UNTIL last year, the kidney was the only organ which had been transplanted with subsequent significant prolongation of life. There had been nine reported attempts at orthotopic liver transplantation; seven in Denver ${ }^{19,22,23}$ and one each in Boston ${ }^{16}$ and Paris. ${ }^{5}$ Two of these patients had succumbed within a few hours after operation, $, 5,22$ and none had lived for longer than 23 days.

This dismal picture has changed within the last 9 months, inasmuch as seven consecutive patients treated with orthotopic liver transplantation from July 23, 1967 to March 17, 1968 all passed through this previously lethal operative and postoperative period. Three of the recipients are still alive after $9,21 / 3$, and 1 months; the others died after $2,3 \frac{1}{2}, 4 \frac{1}{3}$, and 6 months.

\section{Methods}

The Recipients. Summary information for the seven patients is given in Table 1. Their ages were 13 months to 16 years. Six were females. The indications for transplantation, which had been established by earlier explorations at other hospitals, were

Presented before the American Surgical Association, April 17-19, 1968, Boston, Massachusetts.

Supported by United States Public Health Service grants AM-06344, HE-07735, AM-07772, AI-04152, FR-00051, FR-00069, F05-TW-1154, AM-12148 and AI-AM-08898. extrahepatic biliary atresia in five cases and liver cell carcinoma in the other two. The clinical condition of the recipients ranged from fair to moribund. The sickest was Patient 5 who had required repeated paracenteses for several weeks before admission and who, as a complication of this procedure, had developed a continuously draining lower abdominal peritoneal fistula that did not close until a week after transplantation. When the patient arrived in Denver, examination revealed renal failure with oliguria, proteinuria, and a blood urea nitrogen (BUN) of $70 \mathrm{mg} . / 100 \mathrm{ml}$. A few hours before operation massive gastrointestinal hemorrhage developed, probably from esophageal varices. The bleeding continued until after the transplantation had been completed.

This child and the other four with extrahepatic biliary atresia had preoperative serum bilirubin concentration of 16.1 to $30.9 \mathrm{mg}$./100 ml. and alkaline phosphatase levels of 88 to 632 international units (normal 50 to 150 ). Other biochemical measures of hepatic metabolism were typical of this disease ${ }^{14,18}$ with retention of moderately good synthetic function. For example, the prothrombin values ranged from 50 to $100 \%$ of normal and the total serum proteins were 6.5 to $7.9 \mathrm{gm}$. $/ 100 \mathrm{ml}$. The patients had ascites and all 5 had some evidence of pulmonary arteriovenous shunt- 


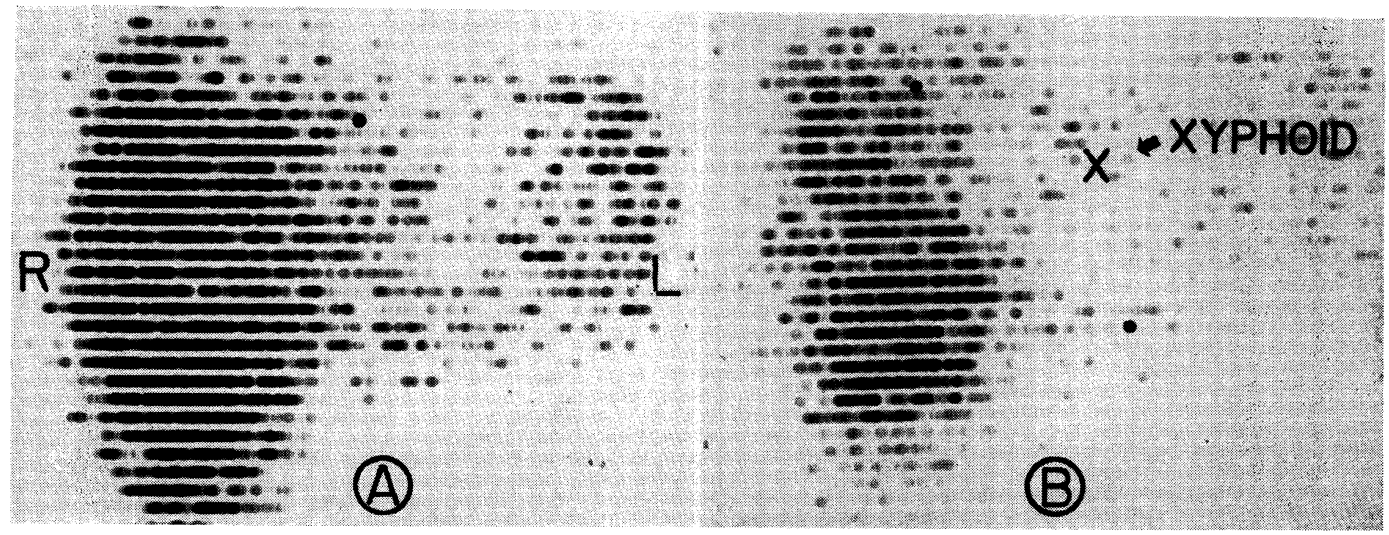

FIG. 1. Growth of a hepatoma in Patient 1. A-Liver scan in February, 1967, using $A u^{188}$. The child was then 13 months old. Most of the tumor was in the left lobe but smaller growths in the right lobe precluded resection. B-A repeat study 3 months later showing only a small remnant of functional liver tissue. The excised liver weighed 1,185 grams.

ing as described in a previous publication..$^{20}$ None had other congenital anomalies.

In Cases 1 and 7, hepatic cell carcinoma was diagnosed 6 months before transplantation. Although both patients were given liver irradiation ( 975 and $3,200 \mathrm{R}$, respectively) and chemotherapy, the tumors had continued to enlarge (Fig. 1). When first seen at our institutions, both children had leukopenia $\left(2,000\right.$ and $\left.3,500 \mathrm{WBC} / \mathrm{mm}^{3}\right)$. They had no evidence of extrahepatic metastases. Liver function was normal.

The Donors. The cadaveric donors were pronounced dead on the basis of cardiac arrest, by members of the service in charge of their care. Previously, all had irreversible central nervous system injury, with no spontaneous respirations and with isoelectric electroencephalograms. In each, life had been maintained for days or weeks with mechanical ventilators and in all but one there had been repeated previous cardiac arrests. After death, ventilatory support and cardiac massage were continued insofar as possible in Cases 1-6 until the organ could be cooled as described below. In Case 7 , the adult donor was placed on cardiac pulmonary bypass 10 minutes after death. This technic ${ }^{15}$ accomplishes both perfusion and cooling of the cadaver at the same time as hepatectomy is being carried out.

The donors and recipients had variable discrepancies of age, size, and weight. The lingering terminal course of the donors made it possible to chose recipients on the basis of histocompatibility analysis in addition to compatibility of red blood cell types (Table 1). In each case the donor lymphocyte antigens were determined both in our laboratories and by Dr. Paul Terasaki of Los Angeles. The histocompatibility profile was used to select the best of several previously studied prospective recipients. The matches eventually accepted are shown in Table 1 . None were perfect, although in Case 1 there were no breeches of 7 major groups of the recently classified human histocompatibility (HLA) system $^{4,26}$; one or 2 group incompatibilities were present in each of the other donorrecipient combinations.

Donor Hepatectomy. Warm ischemia time was minimized by the postmortem resuscitative efforts described above. In addition the livers were core cooled either by the technic of extracorporeal hypothermic perfusion mentioned earlier (Case 7) or by the immediate infusion (Cases 1-6) of cold $\left(2^{\circ}\right.$ C. $)$ balanced electrolyte solution containing heparin, procaine, and low mo- 
The rest of the procedure was essentially

$2^{\circ} \mathrm{C}$ Balanced Electrolyte joiltion

with $50 \mathrm{mgm}$ procalne, $100 \mathrm{mgm}$

weight dextran per liter.

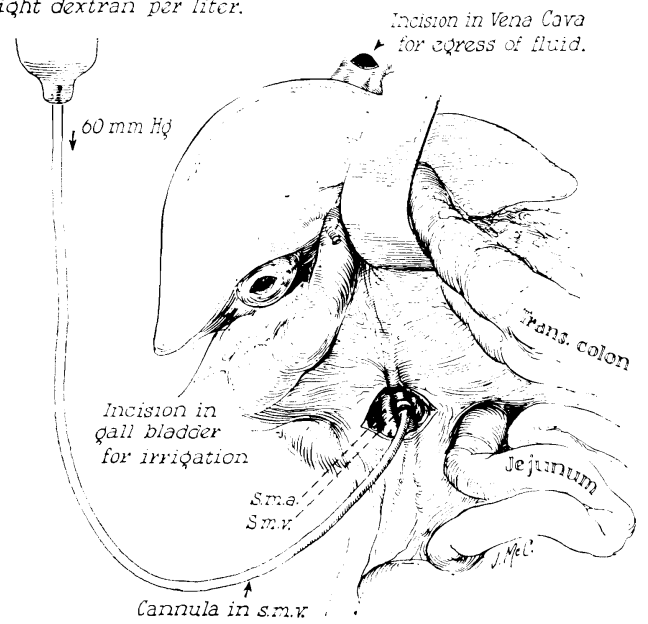

FIG. 2. Core cooling of cadaveric liver used for infant donors. Immediately after entering the abdomen, the cannula is placed into the readily accessible superior mesenteric vein. This vessel is far enough away from the portal triad so that the portal vein, which will ultimately be used for anastomosis, is not in danger of injury. Egress of the perfusion fluid is provided by the venotomy in the suprahepatic inferior vena cava. Bile is washed from the gallbladder through the cholecystotomy For the adult donor (Case 7), the liver was cooled by total body extracorporeal perfusion, and the flushing carried out after completion of the hepatectomy.

lecular weight dextran, through a cannula inserted into the superior mesenteric vein (Fig. 2). With the latter method, egress for the fluid was provided by incising the inferior vena cava. In order to prevent autolysis the gallbladder was opened at its dome and irrigated with saline to remove all bile.

The aorta was removed in continuity with the hepatic artery (or arteries). It was rapidly exposed and mobilized by lifting the spleen and left transverse colon into the wound (Fig. 3), opening the plane between the pancreas and left kidney, dividing the left renal vein, incising the crura of the diaphragm, and ligating and dividing all branches except the superior mesenteric artery and the celiac axis. The superior mesenteric artery was spared until it could be proved that it did not give rise to part of the hepatic arterial supply. the same as that originally described ${ }^{22}$ except that the cannulated superior mesenteric vein was retained with the specimen; this necessitated ligation of the splenic vein and several other tributaries beneath the neck of the pancreas. In 2 cases with anomalies, a small right hepatic artery was found directly posterior to the portal vein and traced back to its origin from the superior mesenteric artery. The latter vessel was ligated distal to this point (Fig. 4C).

During the final stages of excision, a cannula was inserted into the distal aorta and used to flush the arterial tree with balanced electrolyte solution. In all but Case 2, the homografts were then inserted into a preservation unit for one to several hours. The preservation was with the combined technics of hypothermia, hyperbaric oxygenation, and low flow perfusion of both portal and arterial systems with diluted homologous blood of a compatible red cell type. The total flow rates $(6 \mathrm{ml}$./Gm. liver/hour), temperature $\left(4^{\circ} \mathrm{C}\right.$. $)$, times of chamber decompression, and other methodologic details were exactly the same as reported earlier in dog experiments. ${ }^{2}$ When the specimens were subsequently removed from the chamber, the vessels were recut according to the requirements for their anastomoses.

Recipient Operation. In six of the seven patients, the operation was not begun until the homograft was in the chamber and had been checked for defects under conditions of perfusion. A large transverse abdominal incision was used. The most difficult step was excision of the recipients' diseased livers since extensive upper abdominal adhesions and portal hypertension were present. In the patients with biliary atresia, the removed organs weighed 665 to 885 grams. The liver from the 19-month-old child with hepatoma weighed $1,185 \mathrm{Gm}$.; the liver and hepatoma in the 16-year-old girl weighed 2,575 grams. In all but Case 7, the enlarged spleens were removed after the homografts had been placed. 


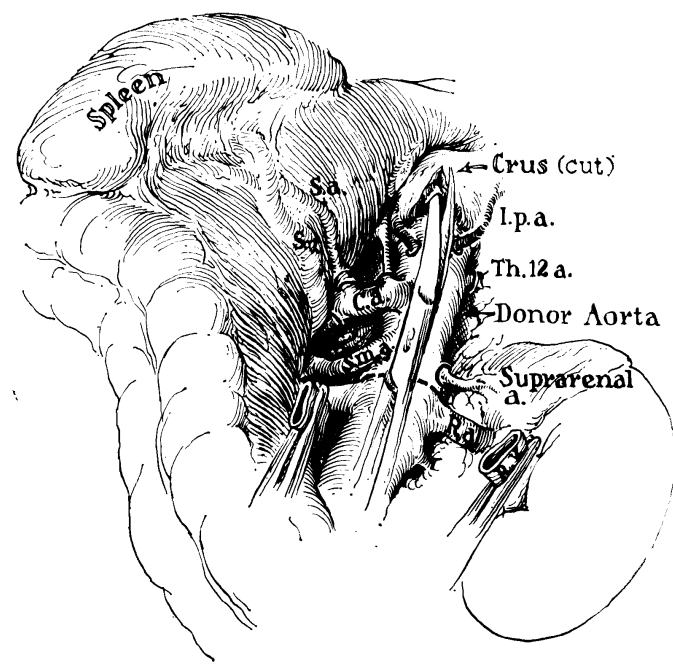

FIG. 3. Mobilization of the aorta during donor hepatectomy. Rapid identification and ligation of the branches is facilitated if variable traction is applied to the distal aorta. During the initial dissection, all the aortic branches except the coeliac axis and superior mesenteric artery are ligated and divided; the latter vessel is cut only after it has been shown not to give rise to an anomalous hepatic arterial branch.

The transplantations were performed with the previously described technic, ${ }^{22}$ with the exception of some important details. Biliary drainage was provided by cholecystoduodenostomy (Fig. 4) instead of choledochocholedochostomy. Another extremely significant change, as recently reported, ${ }^{20}$ was the omission of bypasses to decompress the splanchnic and systemic venous systems during the anhepatic phase. In the seven patients, the portal vein and inferior vena cava were simultaneously occluded for 50 to 90 minutes. The maximum resulting fall in arterial blood pressure was $20 \mathrm{~mm}$. $\mathrm{Hg}$. The intestines became slightly dusky in several cases, but this change was immediately reversed with the restoration of venous return. The order of the anastomoses was suprahepatic vena caval, infrahepatic vena caval, hepatic arterial, and portal venous. In Case 1, the caval clamps were released after the first 2 anastomoses were completed. In the others, no vascular channels were reopened until at least three, or

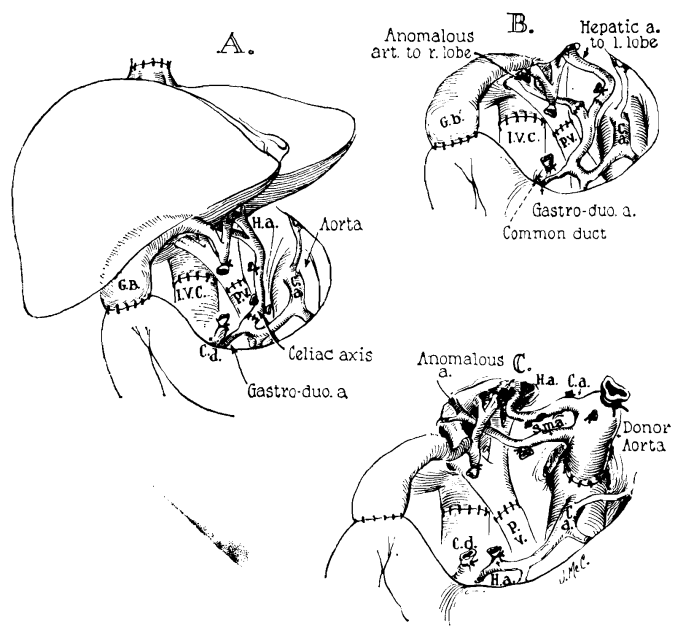

FIG. 4. Recipient operations. Cholecystoduodenostomy was performed in all 7 cases. A-The kind of arterial anastomosis used in Cases 1, 3, 4, 6 , and 7. The homograft coeliac axis or common hepatic artery was attached to the proper or common hepatic artery. B-Arterial anastomoses in Case 2. The right hepatic originated from the superior mesenteric artery. C-Anastomosis of the homograft aorta to the recipient aorta (Case 5). This technic was used because of the double arterial supply.

in two cases, all four vessels had been reconstructed.

In five patients, the homograft hepatic artery or celiac axis was anastomosed to the recipient proper or common hepatic artery (Fig. 4A). In the other two, a separate branch to the right lobe rose from the superior mesenteric artery. The first time the anomaly was encountered (Case 2), the two vessels were individually connected to the right and left branches of the recipient proper hepatic artery (Fig. 4B). The next time (Case 5), the distal donor aorta was anastomosed end-to-side to the upper abdominal aorta of the recipient (Fig. 4C). Liberation of sufficient recipient aorta above the celiac axis required incision of the covering diaphragmatic crus. The anterior aortic wall was isolated with a partial occlusion clamp during the period of suturing. The proximal end of the homograft aorta was ligated a few millimeters beyond the origin of the celiac axis (Fig. 4C). 
Table 1. Data on 7 Recipients of Orthotopic Liver Homografts and Their Cadaveric Donors

\begin{tabular}{|c|c|c|c|c|c|c|c|c|}
\hline Case No. & Age & Sex & Weight (Kg.) & $\begin{array}{l}\text { Blood } \\
\text { Group }\end{array}$ & Disease & $\begin{array}{c}\text { Time Death to } \\
\text { Organ } \\
\text { Revascularization }\end{array}$ & $\begin{array}{r}\text { Terasaki Mis } \\
\text { Major Groups }\end{array}$ & $\begin{array}{l}\text { matches } \\
\text { No. Sera }\end{array}$ \\
\hline 1. Donor & $18 \mathrm{mth}$ & $\mathrm{M}$ & 6.4 & $\mathrm{O}+$ & $\begin{array}{l}\text { Microcephaly; } \\
\text { aspiration } \\
\text { pneumonitis }\end{array}$ & $311 \mathrm{~min}$ & 0 & $4 / 60$ \\
\hline Recipient & $19 \mathrm{mth}$ & $\mathrm{F}$ & 10.8 & $\mathrm{O}+$ & Hepatoma & & & \\
\hline $\begin{array}{l}\text { 2. Donor } \\
\text { Recipient }\end{array}$ & $\begin{array}{r}48 \mathrm{mth} \\
20 \frac{1}{2} \mathrm{mth}\end{array}$ & $\begin{array}{l}\mathrm{F} \\
\mathrm{F}\end{array}$ & $\begin{array}{r}13.0 \\
8.7\end{array}$ & $\begin{array}{l}\mathrm{O}+ \\
\mathrm{O}+\end{array}$ & $\begin{array}{l}\text { Drowning } \\
\text { Biliary atresia* }\end{array}$ & $282 \mathrm{~min}$ & $2(\mathrm{Mac})$ & $14 / 60$ \\
\hline $\begin{array}{l}\text { 3. Donor } \\
\text { Recipient }\end{array}$ & $\begin{array}{l}18 \mathrm{mth} \\
13 \mathrm{mth}\end{array}$ & $\mathrm{F}$ & $\begin{array}{l}8.2 \\
9.4\end{array}$ & $\begin{array}{l}\mathrm{A}+ \\
\mathrm{A}+\end{array}$ & $\begin{array}{l}\text { Acute CNS } \\
\text { Biliary atresia* }\end{array}$ & $271 \mathrm{~min}$ & 5,7 & $8 / 60$ \\
\hline $\begin{array}{l}\text { 4. Donor } \\
\text { Recipient }\end{array}$ & $\begin{array}{l}20 \mathrm{mth} \\
14 \mathrm{mth}\end{array}$ & $\begin{array}{l}\mathrm{F} \\
\mathrm{F}\end{array}$ & $\begin{array}{l}7.3 \\
7.5\end{array}$ & $\begin{array}{l}\mathrm{A}+ \\
\mathrm{A}+\end{array}$ & $\begin{array}{l}\text { Krabbe's disease } \\
\text { Biliary atresia* }\end{array}$ & $252 \mathrm{~min}$ & $2(\mathrm{Mac})$ & $9 / 60$ \\
\hline 5. Donor & $14 \mathrm{mth}$ & $\mathrm{M}$ & 8.5 & $A+$ & $\begin{array}{l}\text { Werdnig-Hoffman's } \\
\text { disease }\end{array}$ & $242 \mathrm{~min}$ & 5,7 & $23 / 60$ \\
\hline Recipient & $16 \mathrm{mth}$ & $\mathrm{F}$ & 7.5 & $A+$ & Biliary atresia* & & & \\
\hline $\begin{array}{l}\text { 6. Donor } \\
\text { Recipient }\end{array}$ & $\begin{array}{l}33 \mathrm{mth} \\
24 \mathrm{mth}\end{array}$ & $\begin{array}{l}\mathrm{M} \\
\mathrm{M}\end{array}$ & $\begin{array}{l}11.4 \\
11.0\end{array}$ & $\begin{array}{l}\mathrm{O}+ \\
\mathrm{O}+\end{array}$ & $\begin{array}{l}\text { Meningitis } \\
\text { Biliary atresia* }\end{array}$ & $323 \mathrm{~min}$ & 3 & $11 / C_{0}$ \\
\hline $\begin{array}{l}\text { 7. Donor } \\
\text { Recipient }\end{array}$ & $\begin{array}{l}27 \mathrm{yr} \\
16 \mathrm{yr}\end{array}$ & $\begin{array}{l}\mathrm{M} \\
\mathrm{F}\end{array}$ & $\begin{array}{l}82.0 \\
39.0\end{array}$ & $\begin{array}{l}\mathrm{O}- \\
\mathrm{O}+\end{array}$ & $\begin{array}{l}\text { GSW of brain } \\
\text { Hepatoma }\end{array}$ & $427 \mathrm{~min}$ & 2 (Mac) & $8 / 60$ \\
\hline
\end{tabular}

* Extrahepatic.

As will be mentioned later, Patients 1-3 had temporary paralysis of the right diaphragm. This was thought to have resulted from crushing of the right phrenic nerve by the vascular clamp which was applied to the suprahepatic inferior vena cava. In Cases 4-7, a longer cuff was developed and care was taken not to include any diaphragm in the bite. The complication was avoided.

Intraoperative and Postoperative Management. Monitoring of metabolic changes was facilitated during operation by the use of a sampling catheter in the radial artery. A continuous intravenous infusion of glucose solution was given at 0.5 to $1 \mathrm{Gm}$./ Kg. per hour during the anhepatic phase. Glucose administration was continued postoperatively. When it was inadvertently stopped in one patient for approximately 20 minutes after return to the recovery room, hypoglycemic convulsions resulted. Within 2 or 3 days there was no longer need for continuous glucose. By this time, all the patients had started eating.
Rapidly developing metabolic acidosis was always seen during the anhepatic interval. Data on these changes in the first four cases has been published ${ }^{20}$ and the findings in the next three were similar. The extent of the acidosis could not be completely characterized since it was intermittently corrected. In the six infants, sodium bicarbonate was infused during the operation in total doses of 27 to $78 \mathrm{mEq}$., as guided by frequent determinations of arterial $\mathrm{pH}, \mathrm{CO}_{2}$, and bicarbonate. The 16year-old girl who weighed $39 \mathrm{Kg}$. received 290 milliequivalents.

Before, during, and for several hours after transplantation, blood coagulation was followed with 11 different tests. These provided a measure of fibrinolysins, platelets, six clotting factors produced by the liver, and Factor VIII (antihemaphilic globulin) which is extrahepatic in origin. These results are being reported separately in detail. ${ }^{9}$ Epsilon amino caproic acid (EACA) was given just after revasculari- 
Fig. 5. Course in Case 1. The patient is still alive 9 months after orthotopic liver transplantation. The indication for operation was hepatoma. Note the high rises in SGOT and SGPT, and the bacteremia which occurred at the time of the initial liver infarction. The later septicemia developed when the patient became leukopenic during treatment with vincristine for tumor metastases. The thoracotomy was for removal of an unexpanded right upper lung lobe. The first two laparotomies were for excision of tumor recurrences. Liver function has been stable for 8 months. $100 \mathrm{R}$-depth dose of local homograft irradiation. The temperatures are the highest for each day.



zation of the liver in Patient 2, but thrombogenic agents were not given to the others.

Methicillin or one of the other narrow spectrum antistaphylococcal drugs were started intravenously before or during operation and continued afterwards. In addition, agents were given which are usually effective against gram negative organisms; these included ampicillin, cephalothin, kanamycin, chloramphenicol, and polymyxin. The choice of antibotics was made on the basis of prior cultures from the recipients' skin, trachea, urine, and feces. Additional cultures were taken during operation from the donor and recipient duodenum and from the donor gallbladder bile. In the event of growth from these locations, an adjustment in therapy based upon sensi-
FIG. 6. Case 2. The original disease was extrahepatic biliary atresia. A double arterial supply was connected as shown in Figure 4B. The right artery thrombosed within 2 days necessitating hepatic resection, and subsequent drainage of a subhepatic abscess. Eventually hepatic and renal failure developed, the latter leading to hyperkalemia and cardiac arrest. Bacteremia and later fungemia were intermittently demonstrated until eventual death from massive intestinal necrosis. Survival was $4 \frac{1}{2}$ months. Acti C-Intravenous actinomycin $\mathrm{C}$ in micrograms. $150 \mathrm{R}$-depth dose of homograft irradiation. The temperatures are the maximums for each day.

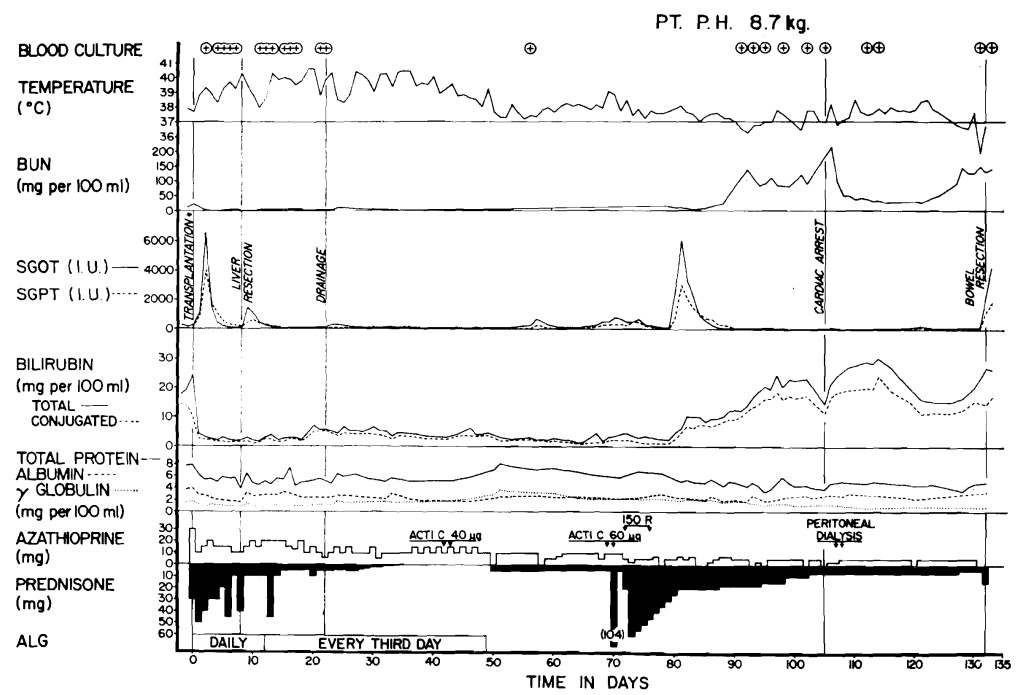




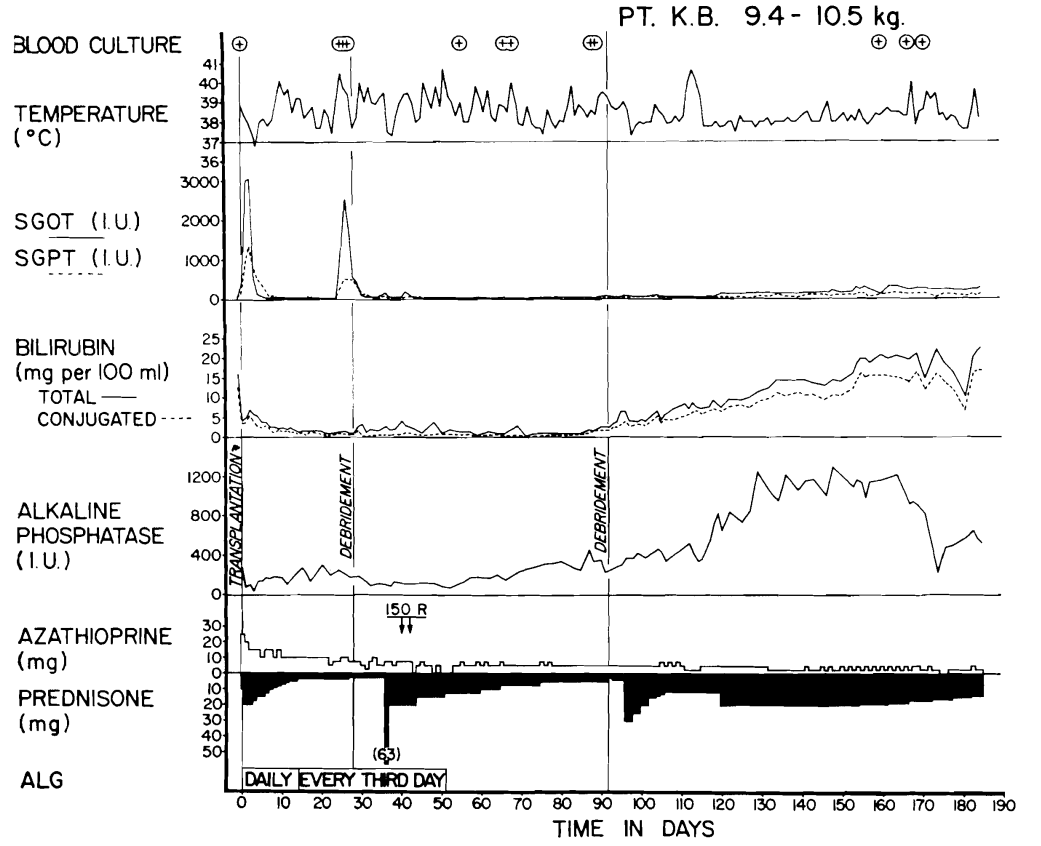

Fig. 7. Course in Case 3 after orthotopic liver transplantation for extrahepatic biliary atresia. Hepatic function was excellent during the first 3 months despite infarctions of large portions of the central and right liver which were treated with debridement. Thereafter, liver failure was progressive. Note the late parallel increases in alkaline phosphatase and bilirubin. The immediate cause of death was intraperitoneal rupture of an undrained residual abscess. Survival was 6 months. Liver irradiation was with $150 \mathrm{H}$ depth dose at each arrow. The temperatures are the daily maximums.

tivity data was made within 24 hours. In two cases, there was enough time to attempt preoperative sterilization of the recipient gastrointestinal tract with a 6 and 48-hour course, respectively, of oral Neomycin, Polymyxin, Cloxacillin and Mycostatin.
Postoperatively, cultures were taken at least twice a week from the wounds, nose, throat, urine, and feces in order to have a continuous record of the endogenous bacterial flora. In addition, blood cultures were obtained 3 or more times a week since it was soon learned that peripheral bactere-

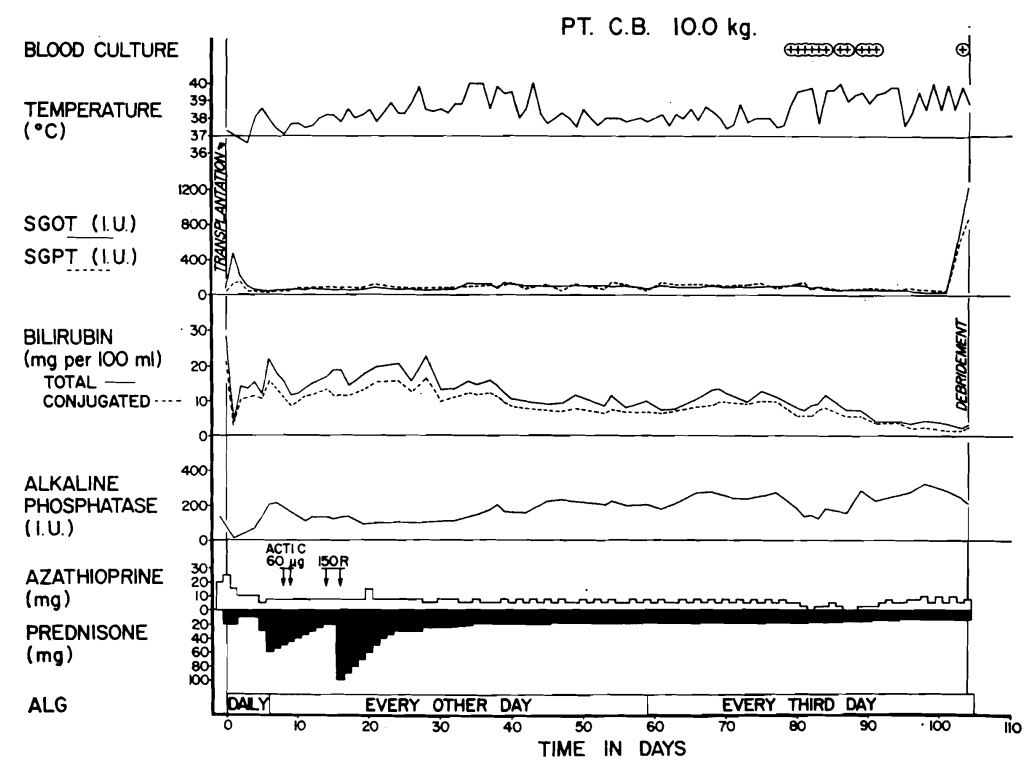

Fic. 8. Course in Case 5 after orthotopic liver transplantation for extrahepatic biliary atresia. A vigorous and protracted rejection began within a few days postoperatively which was not reversed for 10 weeks. Function was improving when persistent gram negative septicemia presaged liver sepsis. Complete right lobar infarction finally occurred causing death within 48 hours. At autopsy. the right hepatic artery was thrombosed. Acti C-intravenous actinomycin $\mathrm{C}$ in micrograms. $150 \mathrm{R}$-homograft irradiation. 
mia could be the first sign of liver sepsis. Frequent changes in antibiotics were made according to the sensitivity of the bacteria in these various locations.

In addition, weekly or biweekly swabs from the nasopharynx, throat, rectum, and urine were obtained for virus isolation. The swabs were immersed in veal infusion broth containing $0.5 \%$ bovine serum albumin; 0.1 $\mathrm{ml}$. was inoculated into monolayer cultures of human diploid fibroblasts (WI-38), primary rhesus monkey kidney cells, and $\mathrm{H}-\mathrm{Ep}^{2}$ cells. The cultures were observed daily for cytopathic effect and tested weekly for hemadsorption with guinea pig erythrocytes. One blind passage was performed for each specimen in each system.

The general plan of immunosuppressive therapy is shown in Figures 5 to 9. Azathioprine, prednisone and heterologous antilymphocyte globulin ${ }^{24}$ were started during the operation. The maintenance doses of azathioprine were usually less than $1 \mathrm{mg}$./ Kg. per day. In Cases 1-4 the quantities of prednisone were rapidly reduced during the first few postoperative weeks (Figs. 5-7) but in Cases 5-7 the steroid withdrawal was at a much slower rate (Figs. $8,9)$. The ALG was given daily for the first one or 2 weeks and then every second or third day. ALG was stopped before the end of the planned 4-month course of therapy in Patients 2 and 4 because of the development of high titers of precipitating antibodies against equine horse protein. ${ }^{12}$ Actinomycin C (40 or $60 \mu \mathrm{g}$.) was intermittently given to Patients 2-5 (Figs. 6, 8). The homografts of Patients 1-5 were irradiated with 2 or 3 doses of 100 or $150 \mathrm{R}$ at depth on alternate days beginning 3 to 13 weeks post-transplantation (Figs. 5-8). The indication for either local $\mathrm{x}$-ray therapy or Actinomycin was rejection.

The function of the transplanted livers was followed with a battery of standard hepatic function tests. In addition, the same clotting studies performed during operation were repeated at one to 4 week inter-

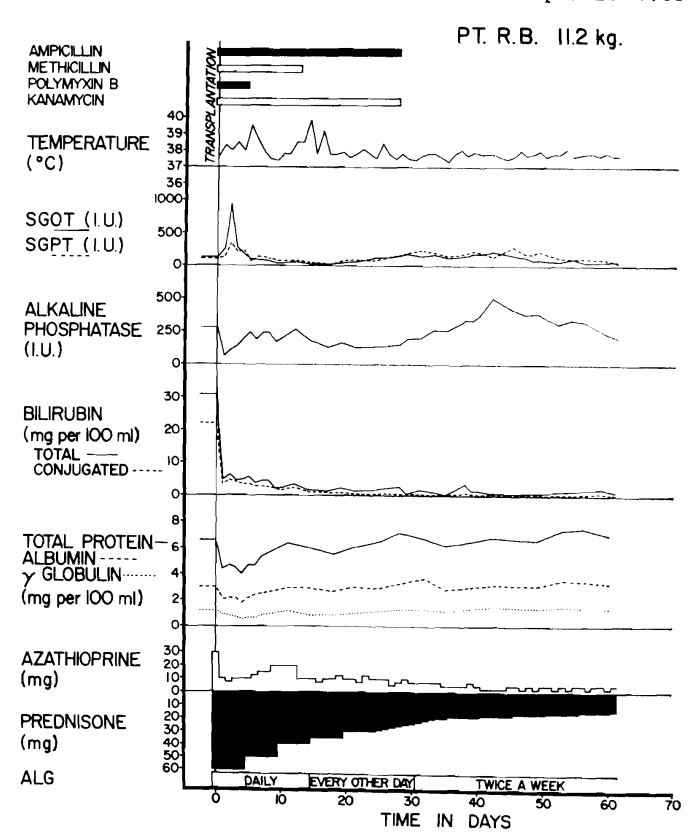

FIG. 9. Course in Case 6. The operation was for extrahepatic biliary atresia. The homograft was immobilized by suturing its ligaments. Jaundice has not recurred, although rejection was diagnosed from the third to seventh postoperative weeks because of the rises in alkaline phosphatase, SGOT, and SGPT; these changes have receded. By 4 weeks, all antibiotic therapy was stopped. The child has since been afebrile. The temperatures are the maximums for each day. An equally benign course has been observed in Case 7 .

vals. Liver scans using a technetium sulfide technic $^{8}$ were obtained every one to 3 weeks or more often if indicated.

Pathological Studies. Paraffin sections were routinely prepared from all tissues. In some instances additional material was fixed in Palade's buffered osmium tetroxide for subsequent electronmicroscopy and in liquid nitrogen for later examination by fluorescent antibody methods. The thin sections for electromicroscopy were stained with lead hydroxide and examined in a Philips EM 300. Sections of the frozen tissue were tested by Drs. Andres, Hsu, and Seegal of Columbia University, with antisera prepared against human immunoglobulins $\mathrm{G}, \mathrm{M}$, and A, BIC/BIA globulins, C'lq and fibrinogen. Appropriate controls were also used. 


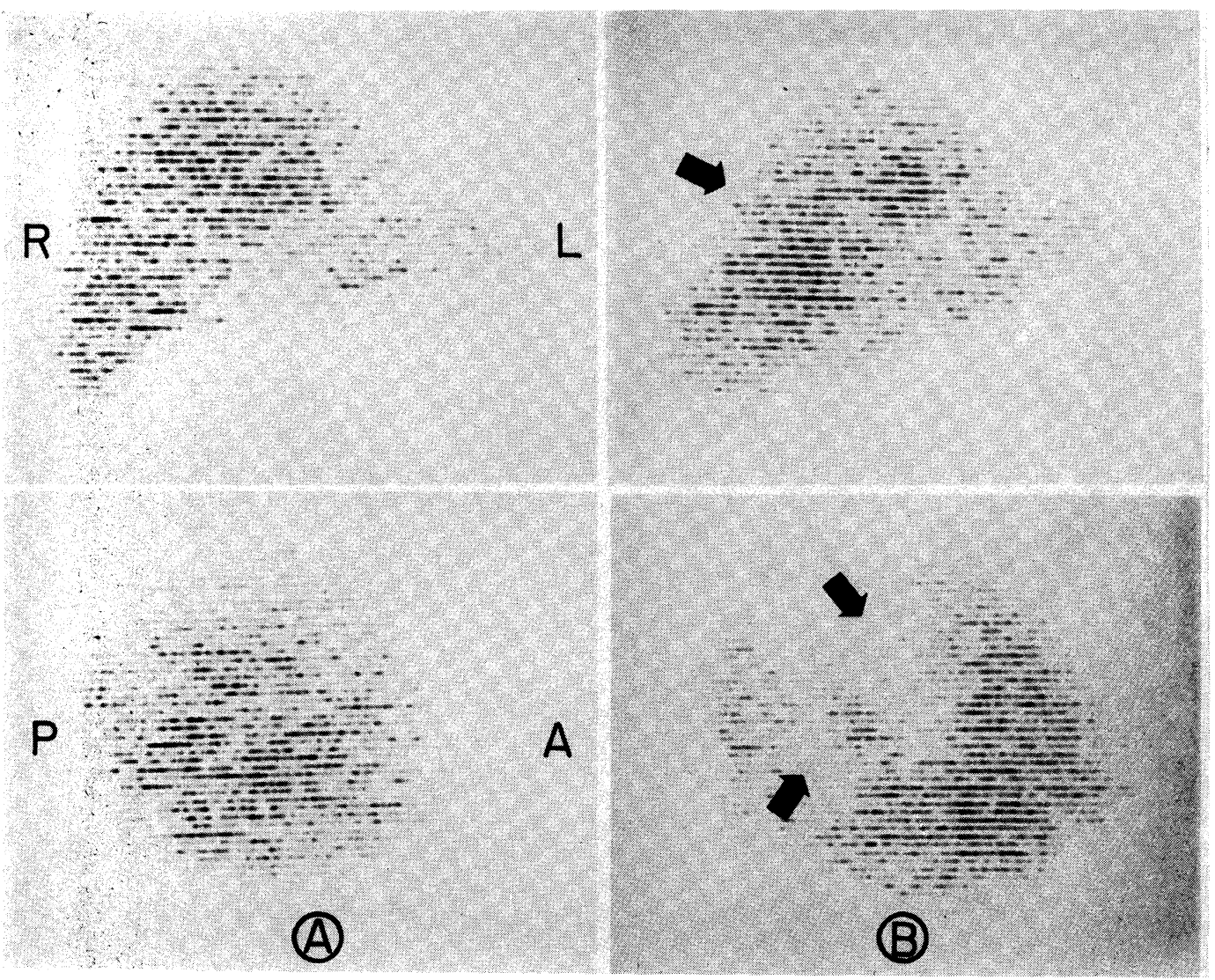

FIG. 10. Radioisotope liver scans in Case 1 obtained with 99M-technetium. A-Seventeen days after transplantation. The isotope uptake is diminished but there are no defects. B-Large non-opacifying areas are demonstrable (arrows) 29 days after transplantation in the posterior part of the right lobe. The patient had septicemia.

\section{Results}

Survival. Patients $2,3,4$ and 5 died $133,186,60$, and 105 days post-transplantation. The three others are still alive with excellent liver function after 269, 68, and 33 days.

Two of the deaths (Cases 4 and 5) occurred within a few days after and were caused by the septic hepatic infarctions to be described below (Fig. 8). The delayed consequences of the same complication were largely responsible for the unfavorable outcome in Cases 2 and 3.

Technical Complications. The iatrogenic right diaphragmatic paralysis in Patients 1-3 persisted for 10,7 , and 2 weeks. In Case 1 , failure of the right upper pulmo- nary lobe to expand prompted its removal during the fourth postoperative week (Fig. 5 ). The subsequent prevention of operative injury to the right phrenic nerve in Cases 4-7 was mentioned earlier.

In performing recipient hepatectomy, the small bowel in one case and the right transverse colon in another were perforated during mobilization of intestinal loops that had been caught at the site of previous hilar dissections. The rents, which were closed in 2 layers, healed without incident.

Earlier attempts at liver transplantation were complicated by fibrinolysis, hypofibrinogenemia, thrombocytopenia and hemorrhage. ${ }^{11,22,27}$ The same clotting abnormalities were seen in the more recent cases as 


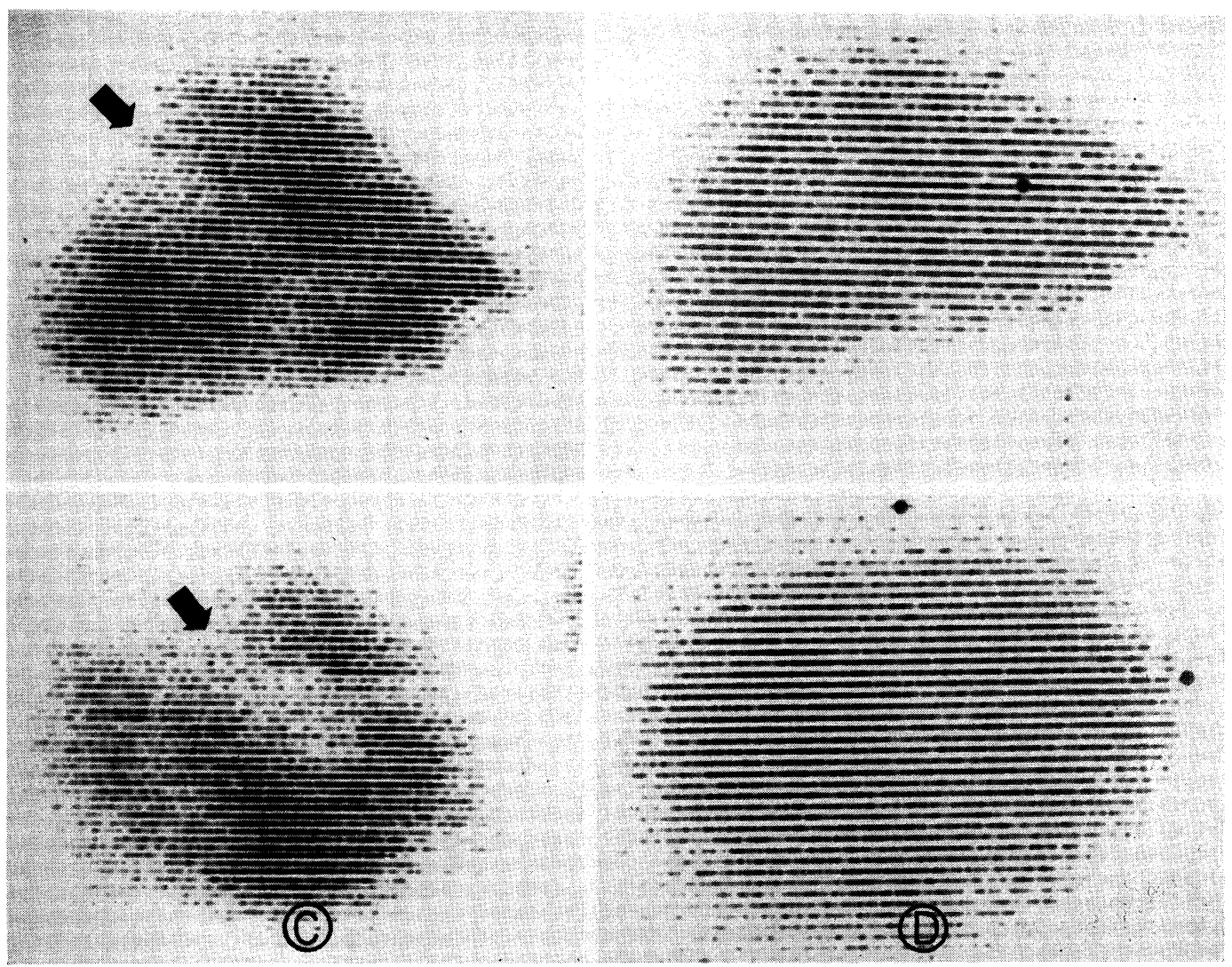

FIG. 10C-Three days later. The necrotic liver tissue had been debrided. D-The defects are no longer seen 252 days after operation. Note that the liver has progressively increased in size.

well as depression of a number of discrete clotting factors produced within or outside the liver; these findings are being reported in detail elsewhere. ${ }^{9}$ Nevertheless, bleeding was not a difficult problem. In the infants, the estimated blood loss ranged from 460 to $1,200 \mathrm{ml}$. (average $790 \mathrm{ml}$.). The 16 year-old girl received $4,000 \mathrm{ml}$. transfusion, almost all as the result of hemorrhage during hepatectomy.

Homograft Sepsis. Two to 104 days after transplantation, five of the seven patients developed gram negative septicemia with a variety of microorganisms including Aerobacter-Klebsiella, Escherichia coli, and Bacteroides. Bilirubin, alkaline phosphatases, serum proteins, and prothrombin times were little affected if at all, but there were high rises in the SGOT and SGPT (Figs. 5-8). Liver scans showed large defects, involving principally the right lobe (Figs. $10,11)$. Each of the patients had developed a septic hepatic infarct.

This complication was not easily controlled in spite of specific antibiotic therapy and excisions, extraperitoneal debridements (Fig. 12), and drainage. Two of the five patients died within a few days. The other three, who initially survived the complication of regional hepatic gangrene, had a protracted subsequent morbidity. The tracts running to the subphrenic space (Case 2) or within the liver (Cases 1 and 3 ) were irrigated and probed every day. They could not be kept sterile in spite of local and systemic antibiotics. The same 

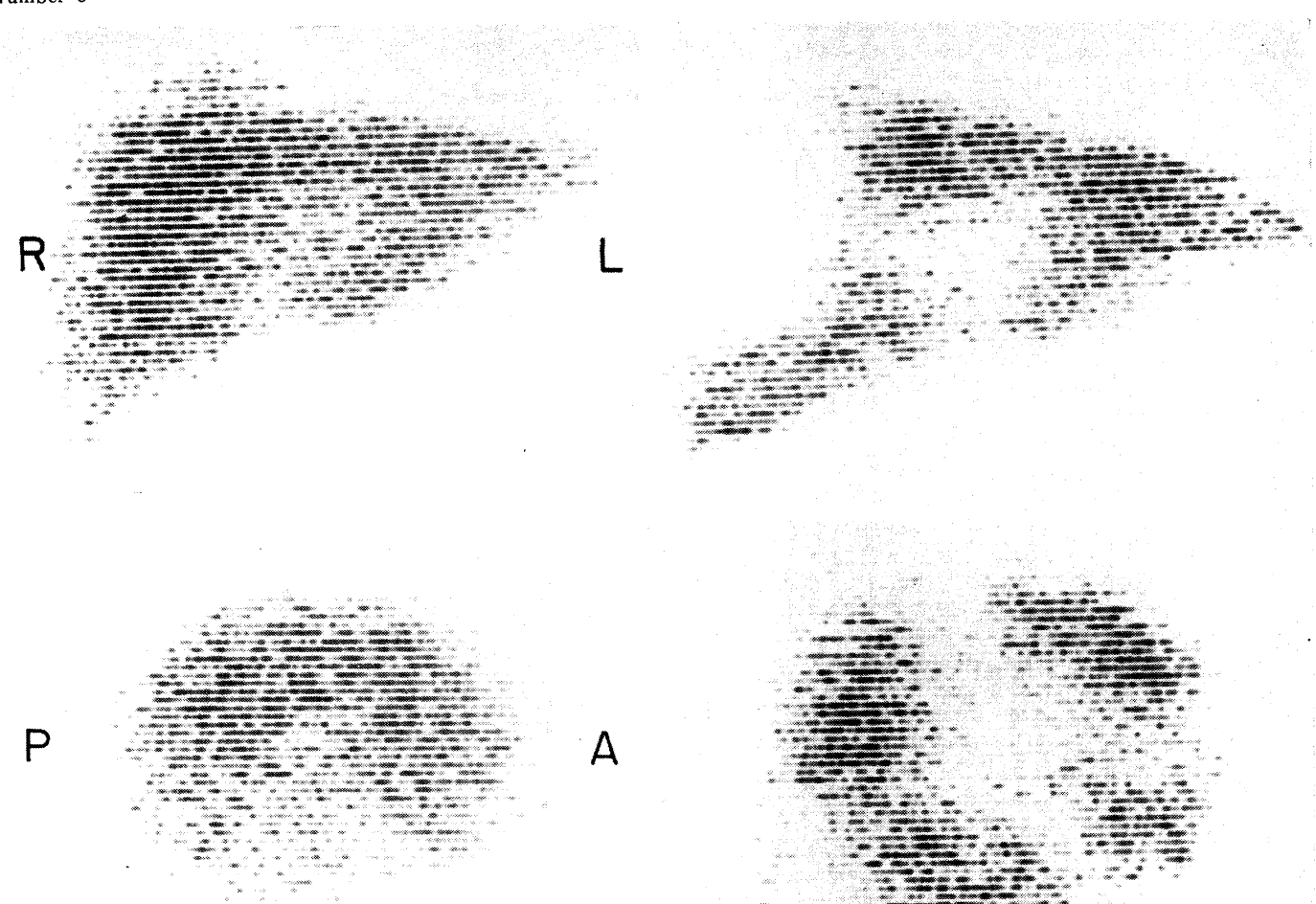

A

(A)

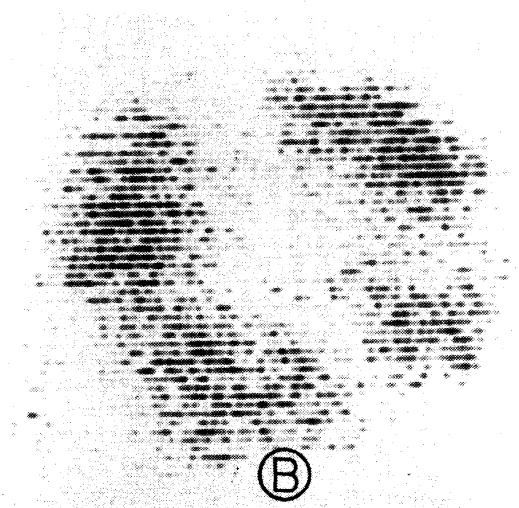

FIG. 11. Radioisotope liver scans in Case 3. A-Normal scan 10 days post-transplantation. B-Non-opacifying areas in the right and central parts of the liver 27 days postoperatively. Septicemia had developed.

organisms cultured from the draining wounds appeared from time to time in the blood stream necessitating reoperation and more extensive debridements (Figs. 5-7). At these times it was noticed that plugs of dead tissue radiated from the main tracts, often surrounding thrombosed intrahepatic portal triads. Between debridements there was variable evidence from the scans that filling in of the defects was occurring as the consequence of hepatic regeneration (Figs. 10, 11). Nevertheless, the open wounds never completely healed, even after more than 8 months in Case 1 .

Early Liver Function. During the first few postoperative days, all seven of the patients had moderate but rapidly reversible rises in SGOT and SGPT. In spite of this evidence of ischemic injury, the livers provided life sustaining function from the be- ginning. The two recipients with normal bilirubin values before operation did not become jaundiced within the first postoperative week and the five patients with biliary atresia had rapid partial or complete disappearance of hyperbilirubinemia (Figs. 6-9). Alkaline phosphatases decreased from 140-632 to 27-165 units during the first week.

All the recipients had a transient fall in total serum proteins (Figs. 5-9), the lowest value in the first postoperative week being $3.4 \mathrm{Gm} . / 100 \mathrm{ml}$. in Case 3. The three children with the most severe acute hypoproteinemia developed transient peripheral edema which resolved as the serum proteins began to rise.

The serum protein depression appeared to be due at least partly to an increased protein loss or heightened catabolism, 


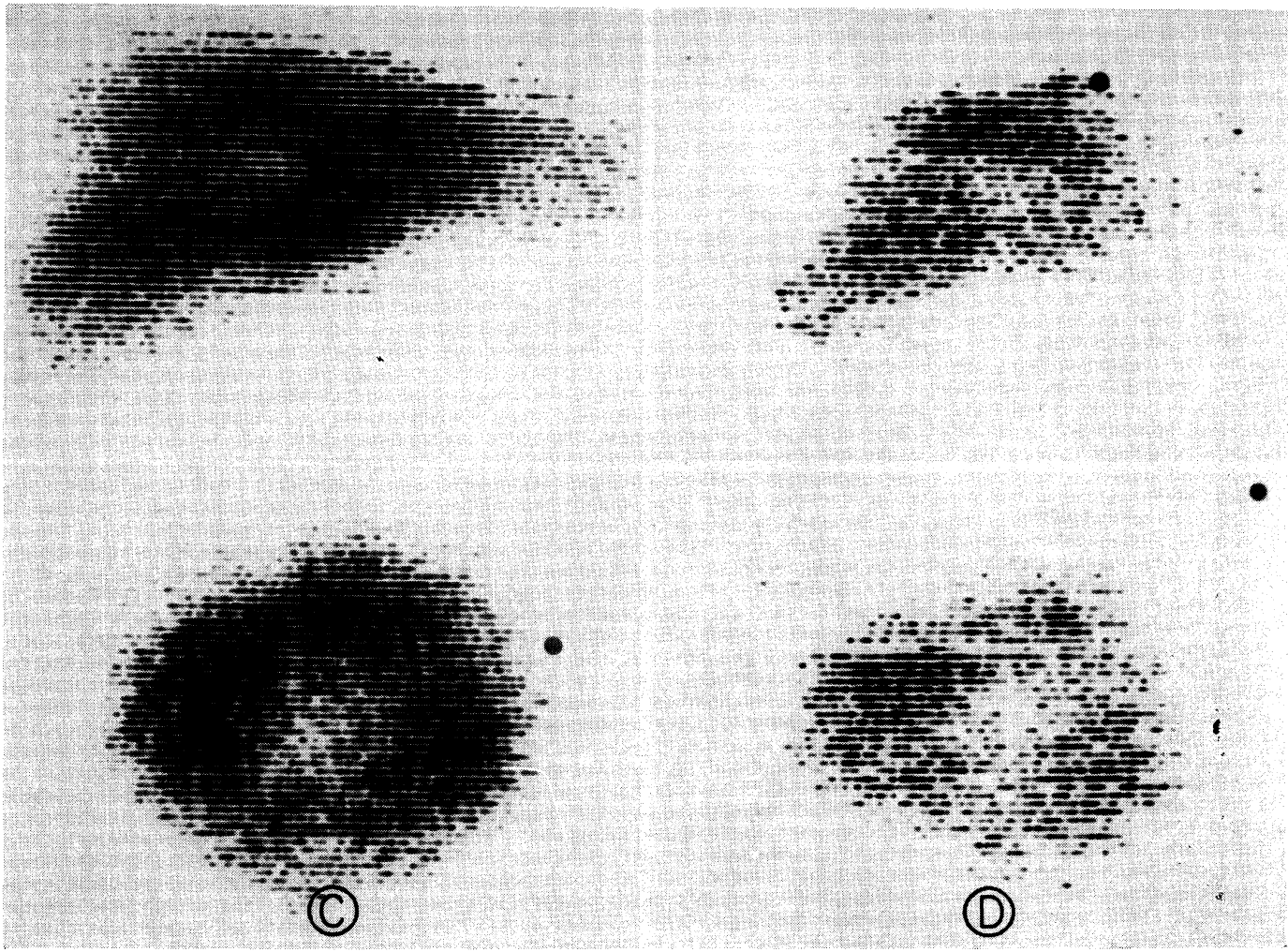

FIG. 11C-The necrotic areas were debrided. There was evidence of regeneration 84 days post-transplantation. Liver function was still excellent. D-Liver shrinkage and diminished isotope uptake 176 days after transplantation. The child died 10 days later when an abscess in the left lobe ruptured into the peritoneal cavity.

rather than to a failure of synthesis. The plasma levels of Factors I (fibrinogen), II (prothrombin), V (Accelerator globulin), VII (proconvertin), IX (Christmas) and $\mathrm{X}$ (Stuart) which are manufactured by the liver were maintained above 50 to $70 \%$ of normal in all seven patients from the first to the seventh days. ${ }^{9}$ In addition, Kashiwagi et $a l . .^{13}$ have shown that the identifiable protein genotypes haptoglobin and group specific component, which are synthesized only in the liver, changed within hours to that of the donor. Their studies suggested that there was a considerably accelerated protein turnover.

Subsequent Liver Function. Evaluation of later function was difficult in all the patients (Cases 1-5) who developed septic hepatic infarctions. A course analogous to that seen after canine homotransplantation to immunosuppressed recipients ${ }^{21,25}$ was seen only in Cases 6 and 7 in which the complication of regional hepatic gangrene has thus far been avoided.

Both of the latter two patients apparently had a rejection episode. The first had moderate and reversible increases in SGOT, SGPT, and alkaline phosphatase but without the recurrence of hyperbilirubinemia (Fig. 9). Very similar enzyme changes were seen in Case 7 beginning in the second postoperative week but in this patient the serum bilirubin concomitantly rose to $6 \mathrm{mg}$. $/ 100 \mathrm{ml}$. and then began to fall again as the SGOT, SGPT, and alkaline phosphatases returned toward normal. At these times, there was little or no depression in either patient in the concentrations of 


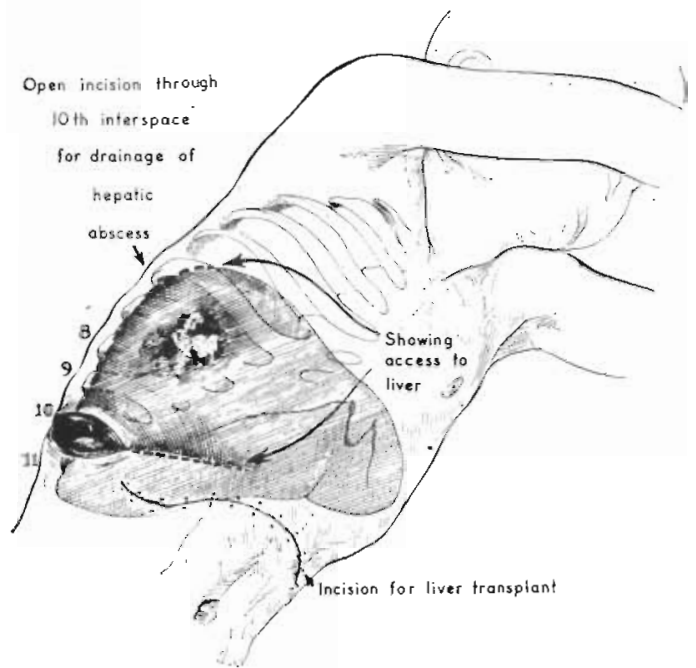

Fic. 12. Operative approach to septic liver infarctions through the 10 th intercostal space. Neither the pleural or peritoneal cavities were entered.

plasma proteins or of 6 measured clotting factors which are synthesized by the liver.

Changes in SGOT and SGPT had a different significance in the five patients who developed regional hepatic gangrene. With this complication, the transaminase rises were higher and more abrupt (Figs. 5-8) than those associated with rejection and they were usually accompanied by minimal acute alterations in other measures of liver function. In Cases $1-3$ there was little other evidence to support the diagnosis of rejection at that time (Figs. 5-7). Difficult rejections had already occurred in Cases 4 and 5 but these appeared to have long since been reversed at least in terms of resolution of jaundice (Fig. 8).

In the three patients who did not die as the immediate consequence of septic liver infarction, it was difficult to differentiate the subsequent adverse effects of this complication from those of chronic rejection. The child whose preoperative diagnosis was hepatoma (Fig. 5) has had stable excretory and synthetic hepatic function (including normal levels of all six of the analyzed liver-based clotting factors) in the 8 months since debridement procedures.
In contrast, progressive liver failure developed about 2 months after the septic hepatic infarctions in Cases 2 and 3 (Figs. 6 and 7 ), with jaundice, alkaline phosphatemia and eventual depression of all studied plasma proteins. The latter two children redeveloped the extensive venous collaterals on the abdomen which had been present preoperatively and in one of them ascites recurred; eventually, homograft shrinkage was clemonstrated with liver scans (Fig. 11).

Extrahepatic Infections. Five of the seven patients had evanescent parahilar or lower lobar infiltrations during the early course, for which a bacterial or viral etiology could not then be established. Subsequently, Patient 5 persistently had cytomegalovirus (CMV) in tracheal excretions from postoperative days 75 to 105 at the same time as diffuse pneumonitis and Aerobacter-Klebsiella bacteremia developed (Fig. 8). At autopsy, there was extensive bilateral pneumonia and histologic evidence of lung infestation with bacteria, cytomegalovirus, and Pneumocystis carinii. In another patient (Case 3) chronic pneumonitis was evident radiographically for the last 3 months of life. Fungal and viral studies of the autopsy specimens have thus far been inconclusive. Finally the second infant in the series had CMV in tracheal secretions on two occasions but never developed symptoms or abnormalities of her chest $\mathrm{x}$-ray. At autopsy, there was no histologic evidence of CMV in the lungs but there was moderately severe infestation with Pneumocystis carinii.

Transient fungemia was detected in Cases 1, 2, and 4 during the sixth, fourth, and first postoperative months. Patients 1 and 2 were infected with Candida albicans and were given intravenous Amphotericin $\mathrm{B}$ and an investigational drug 5-fluorocytosine, ${ }^{\circ}$ respectively; the latter agent which

- Roche Company, Professional Service Department, 212 Oxford, New York, N. Y. 


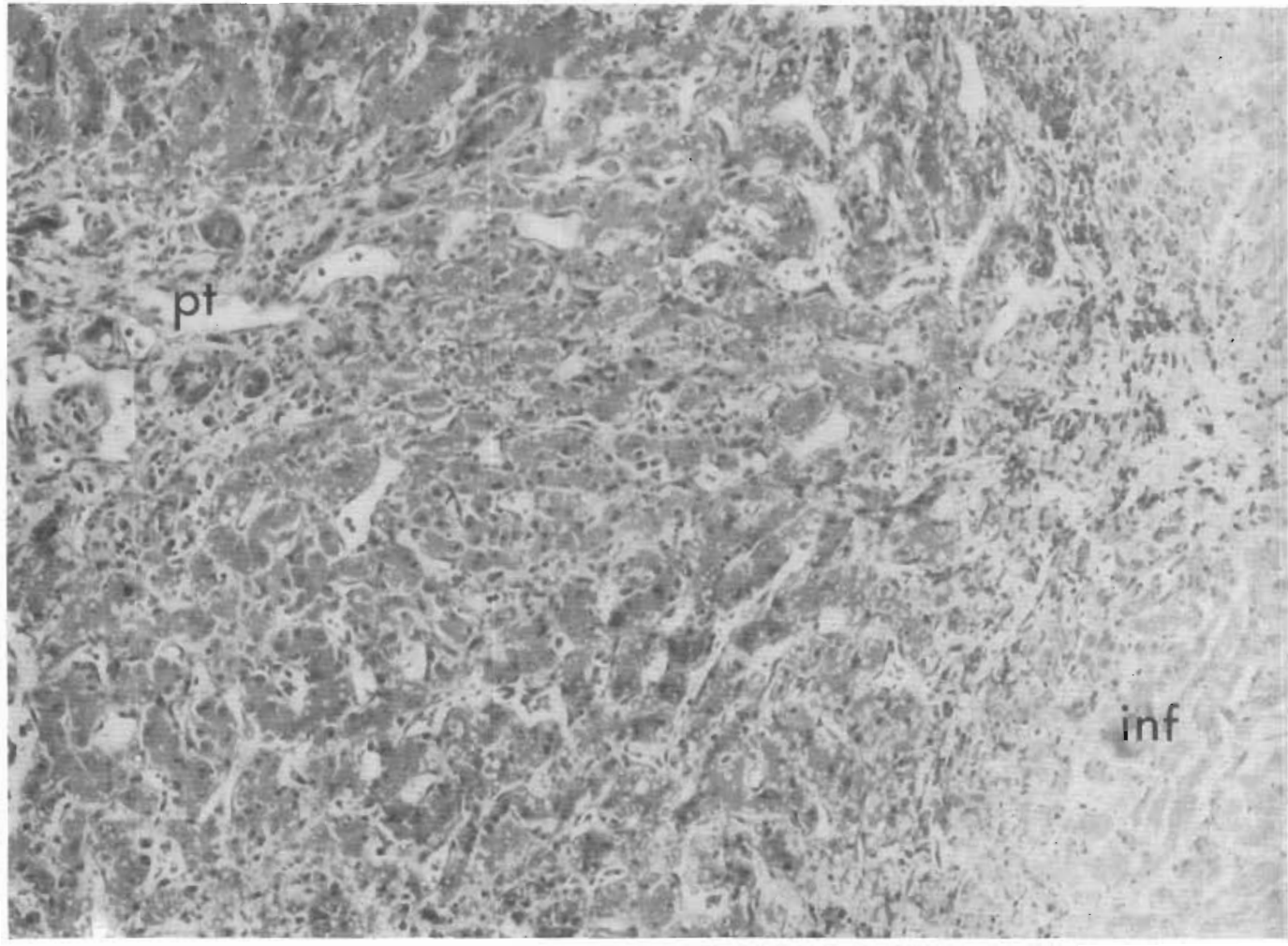

Frg. 13. Hepatic homograft from Patient 4 two months after transplantation. A large infarct (inf) in the right lobe ic separated from the viable liver by a rim of fibroblasts and small lymphocytes. There is excess fibrous tissue and several small bile ductules in the portal tract (pt). $\mathrm{H} \& \mathrm{~F}(\times 180$.

is less nephrotoxic than Amphotericin was used because the patient had azotemia. Patient 4, who had an unidentified yeast, was treated with Amphotericin B. In all three cases the fungemia ceased after the beginning of therapy. Two of the children subsequently died. In one, a fungal infection could not be found at autopsy. Multiple fungal brain abscesses were present in the other.

Asymptomatic Herpes simplex virus excretion was demonstrated in the 16-yearold recipient, beginning 3 weeks after transplantation. This girl has a past history of recurrent Herpes simplex mucocutaneous lesions.

Other Complications. Concomitant with progressive liver failure, and shortly after she had been treated with both kanamycin. and Polymyxin, Patient 2 developed a se- ries of renal complications including azotemia, oliguria, secondary electrolyte disequilibrium, and cardiac arrest caused by hyperkalemia. She was resuscitated with cardiac massage and then treated with peritoneal dialysis for 48 hours. She lived for another 4 weeks until necrosis developed of the entire small intestine. At exploration the involved bowel was resected. Almost all of the intestinal veins and many of the small arteries were thrombosed. She died 24 hours later.

The child treated for hepatoma (Case 1) developed multiple metastases in the lungs and abdomen during the fourth postoperative month. Two of the intra-abdominal recurrences were excised 3 and $7 / 2$ months after transplantation. The first which weighed $28 \mathrm{Gm}$. was superior to the right transverse colon. The second, which par- 


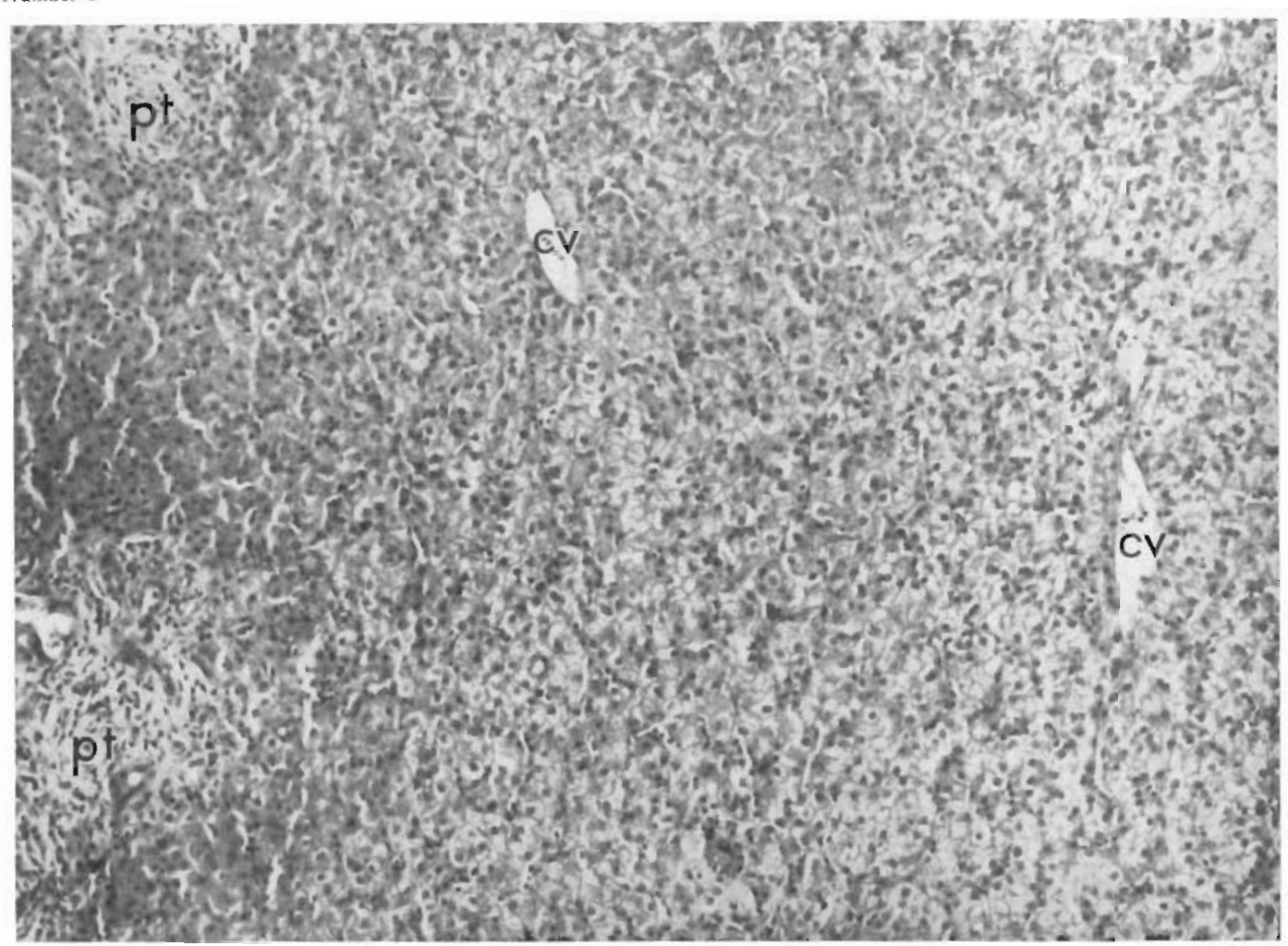

Fic. 14. Patient 1. Biopsy of hepatic homograft 100 days after transplantation. In the portal tracts (pt) the amount of fibrous issue is increased and there are small bile ductules and a few infiltrating lymphocytes. The central veins $(\mathrm{cv})$ and hepatocytes appear normal. $\mathrm{H} \& \mathrm{E}$ $(x 180$.

tially obstructed the sigmoid colon and left ureter at the pelvic brim, weighed $164 \mathrm{Gm}$.; one month later adhesiolysis was necessary because of intestinal obstruction. A course of 0.02 to $0.1 \mathrm{mg} . / \mathrm{Kg}$. of intravenous vincristin sulfate (Oncovin ${ }^{\circledR}$ ) for 7 weeks, started in the fourth postoperative month, did not halt the growth.

Gastrointestinal bleeding has previously been noted after orthotopic liver transplantation in dogs, ${ }^{6,21,25}$ pigs, ${ }^{17}$ and man..$^{19,23}$ Serious postoperative hemorrhage from the gastrointestinal tract was not observed in any of the seven patients although occult melena was often seen. Antacid therapy was routinely provided.

Pathologic Studies. As a result of the debridement procedures, homograft tissue became available from 8 to 54 days after transplantation in Cases 1-4. A biopsy was obtained after 100 days from the liver of Patient 1. The homografts of Patients 2, 3,4 , and 5 were removed at autopsy.

The pieces of liver removed from $\mathrm{Pa}$ tients $1-5$ at debridement of the right hepatic lobe all contained multiple infarcts. In the necrotic centers of many of these there were large numbers of gram negative bacilli. The infarcts were rimmed by abundant neutrophile polymorphonuclear leukocytes, many eosinophiles and some lymphoid cells. Multiple infarcts were also present in the hepatic homografts removed from Patients $2-5$ at autopsy. The areas of dead tissue were predominantly in the right lobe and were surrounded by a zone of proliferating fibroblasts and by small lymphocytes (Fig. 13). Several of the infarcts contained gram negative bacteria. In $\mathrm{Pa}$ tients 2,3 , and 4 thrombosis of the right 


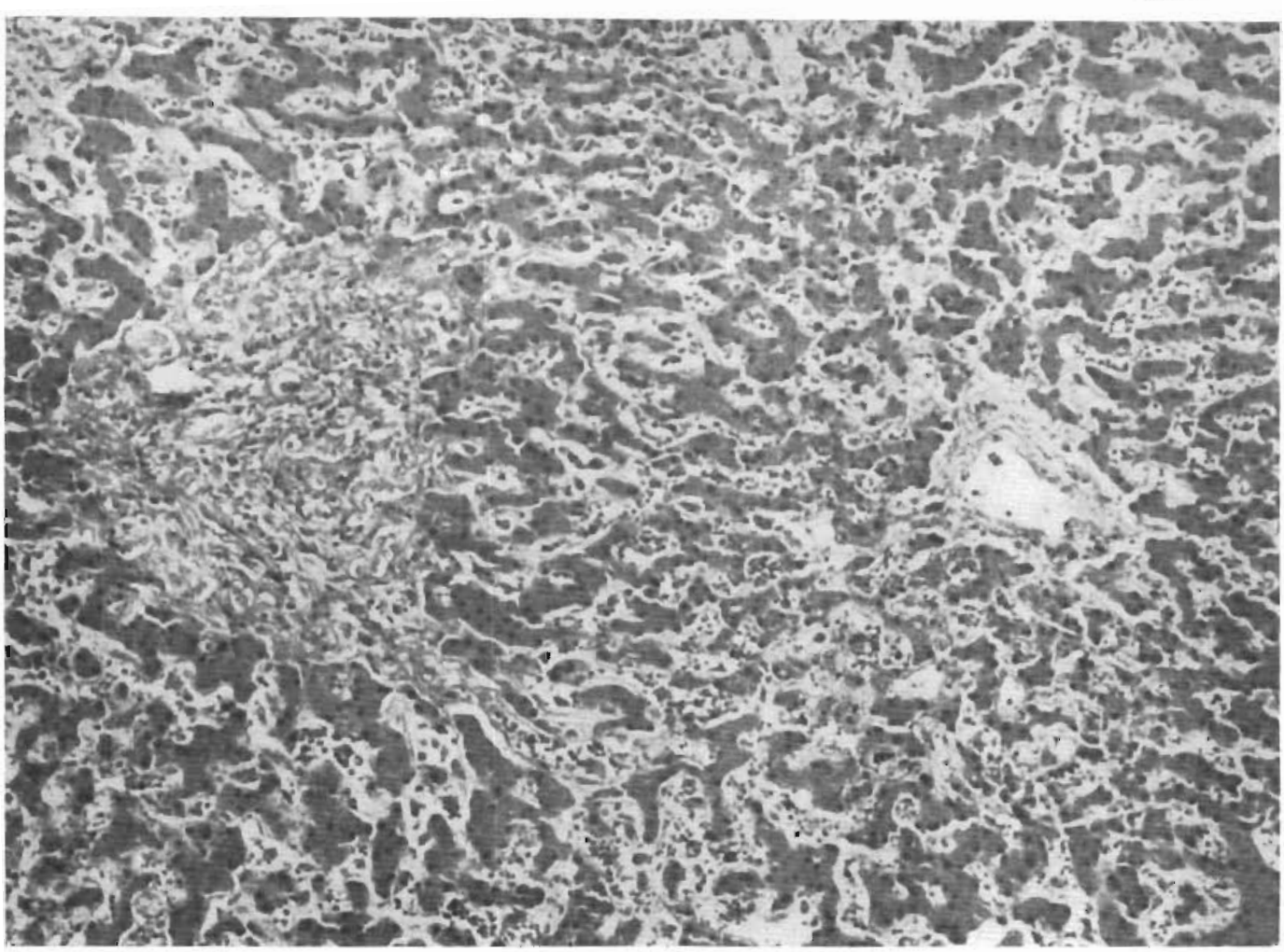

FIG. 15. Patient 5. Hepatic homograft removed at autopsy 31/2 months after transplantation. The portal fibrosis is more marked than in Patient 1. The Kupffer cells are prominent. $(H \& E \times 180$.)

hepatic artery could be seen with the naked eye; in Patient 5 microscopy showed obliteration of this part of the arterial tree by organized thrombus.

The pathological changes in the noninfarcted parts of the liver varied in degree in the five cases. The liver biopsy obtained from Patient 1, 100 days after hepatic transplantation, was the least abnormal (Fig. 14). In the portal tracts there was a moderately dense focal cellular infiltration. The majority of these cells were small lymphocytes, but about $5 \%$ were plasma cells with IgM in their cytoplasm. Several were neutrophile polymorphs; a few were eosinophiles. There was a slight increase in the amount of portal reticulin and collagen and new bile ductules were present in the portal tracts. The Kupffer cells were prominent but not increased in number. A few of the centrilobular bile canaliculi contained small bile "thrombi." There were no alterations in the fine structure of the hepatocytes and the blood vessels were normal. The lack of important pathological changes in this liver correlated well with the good match of donor and recipient shown by lymphocyte typing.

Similar, but slightly more pronounced changes, were present in the liver homografts removed from Patients 4 and 5 at 2 and $3 \frac{1}{2}$ months, respectively, after transplantation (Fig, 15). Although the portal fibrosis was marked there was no linking of adjacent tracts. There were many proliferating small bile ductules and in Patient 5 the bile ducts were dilated and filled with casts that were composed of inspissated bile, surrounded by neutrophile poly- 


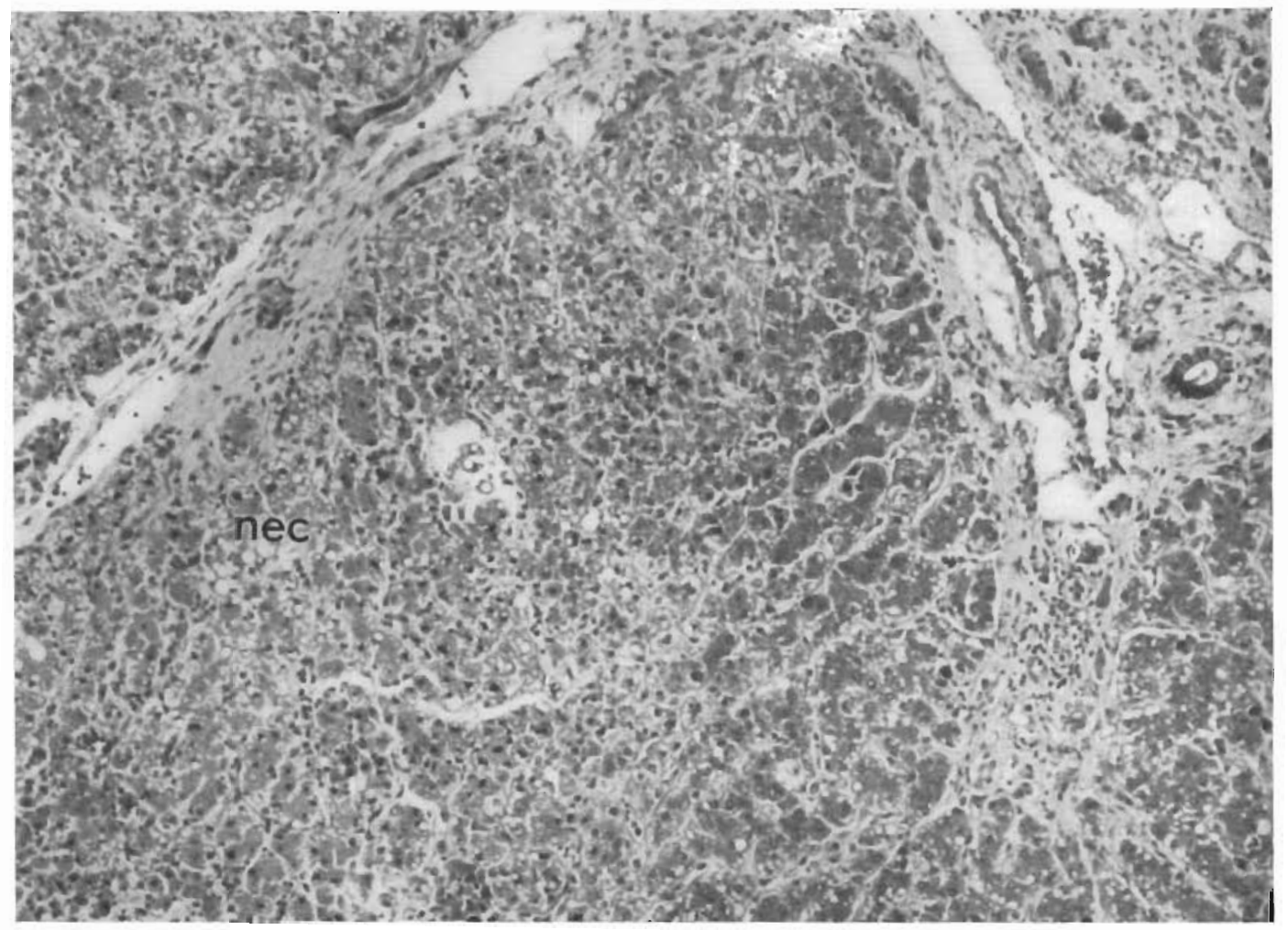

FiG. 16. Patient 2. Liver graft removed at autopsy $41 / 2$ months after transplantation. The normal lobular architecture is interrupted by bands of connective tissue. Part of the liver is necrotic (nec). ( $\mathrm{H} \& \mathrm{E} \times 180$.

morphs. Cellular infiltration in these livers was slight.

The most severely damaged homografts were those from the long surviving Patients 2 and 3. In Patient 2 the portal fibrosis had progressed to cirrhosis. There was linking of portal tract to portal tract and portal tract to central vein by bands of fibrous tissue. The normal lobular architecture of the liver had been lost and there were small regeneration nodules. Areas of liver cell necrosis were present (Fig. 16). Some hepatic artery branches showed slight to moderate degrees of fibrous intimal thickening. In Patient 3 there was portal fibrosis but not cirrhosis. Many of the small branches of the hepatic artery were greatly narrowed or obliterated by intimal thickening. The thickened intima contained collagen and large fat-laden cells. In some of the affected vessels the internal elastic lamina was ruptured. Cellular infiltration was slight, there being only a few foci of small lymphocytes in the portal tracts. This was in contrast to the dense lymphoid cell infiltration seen in the hepatic tissue removed from this same patient 27 days after transplantation.

\section{Discussion}

Survival in all 7 of the presently reported cases exceeded that obtained previously in human trials. ${ }^{5,16,19,22,23}$ The results have established that the actual operative procedure can be done in man with relative safety and that subsequent survival is possible for at least as long as 9 months. The course after transplantation of these children was markedly different than that of earlier recipients of orthotopic liver homo- 
grafts inasmuch as all but one of the patients had a very satisfactory early postoperative convalescence. As discussed elsewhere, ${ }^{20}$ the difference was probably due principally to several improvements in care including more discriminating donor selection, the employment of an efficient method of interim organ preservation, and improved immunosuppressive agents.

Three of the seven patients are still alive 9 months, $21 / 3$ months, and one month after transplantation. The other 4 died after 2 , $3 \frac{1}{2}, 4 \frac{1}{2}$, and 6 months. In each case of the unsuccessfully treated recipients, the development of a septic liver infarction either caused or significantly contributed to the unfavorable outcome. Even the child who is alive after 9 months developed the same life threatening complication. As reported earlier, ${ }^{20}$ the sequence of events seemed to be, first, infarction of portions of the homografts and, then, overgrowth of gram negative bacteria in the necrotic areas. Fortunately, progress has been made in understanding the etiology of these disasters.

Clearly an important factor is the natural susceptibility of the liver to bacterial contamination via the portal vein or biliary tract. In a recent study in dogs and pigs which were not given antibiotic therapy ${ }^{3}$ it was shown that the incidence of positive cultures from liver tissue was increased after simple sham operations in which the liver was not disturbed. When an ischemic injury was added by performance of simulated autotransplantation, all livers became contaminated. The bacteriologic changes were even more pronounced in liver homografts transplanted either to unmodified or immunosuppressed recipients. It was concluded that the numbers of bacteria in the liver reflected more or less accurately the magnitude of hepatic injury from mechanical causes as well as from rejection. These studies help explain the previously reported variable incidence of liver abscess formation after autotransplantation ${ }^{1}$ or homotransplantation of the canine liver ${ }^{21}{ }^{25}$; pre-

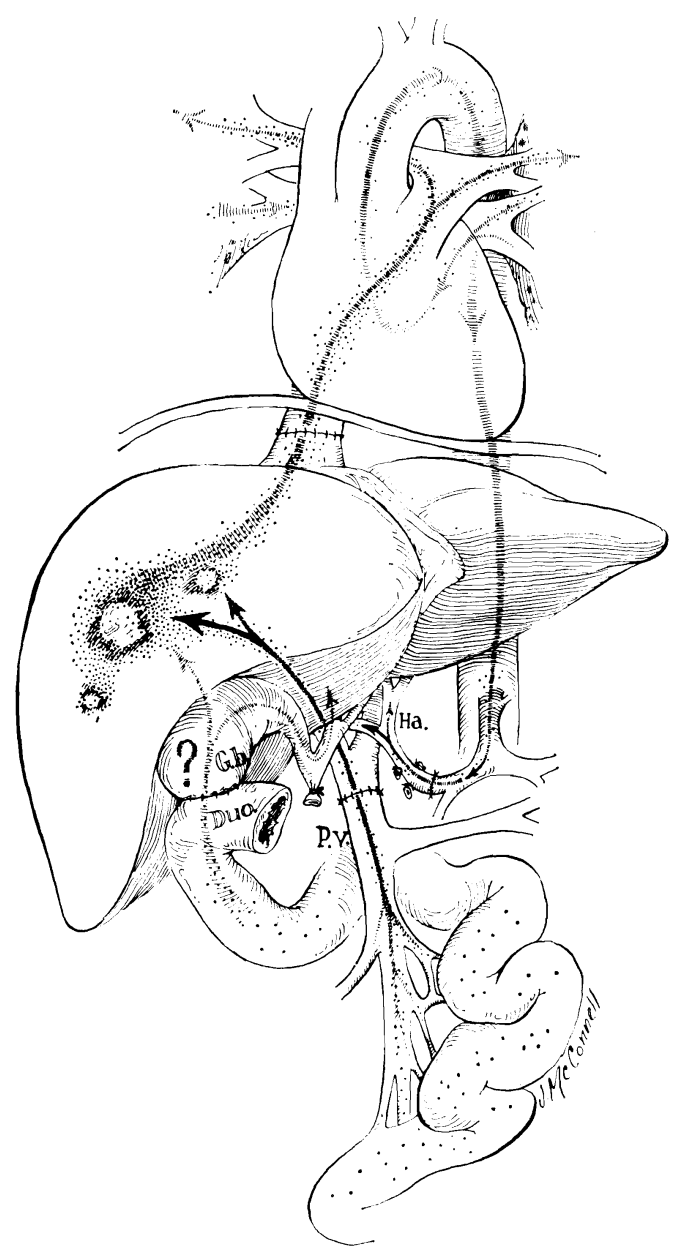

FIG. 17. An anatomical explanation of the predisposition of the liver to bacterial sepsis. Presumably the invading microorganisms enter via the portal vein or through the reconstructed biliary tract.

sumably, any necrotic focus could become infected and serve as the beginning of an abscess cavity (Fig. 17) particularly if the host were being given immunosuppressive therapy. They do not, however, fully explain the syndrome encountered in five of the seven human recipients.

The patients did not have discrete abscesses. Instead, the precipitating event seemed to be dearterialization of part or all of the right hepatic lobe. Studies of the debrided necrotic tissue ${ }^{20}$ suggested acute ischemic infarctions in the right lobe which 
in some areas had not yet become invaded by microorganisms. Furthermore, thrombosis of the right hepatic artery was proved either at operation or autopsy in all four of the patients who died. In another child recently treated by Fonkalsrud, ${ }^{7}$ the same kind of selective thrombosis of the right hepatic artery was the cause of death 2 weeks after liver replacement for extrahepatic biliary atresia.

In an earlier report, ${ }^{20}$ we speculated that the ischemic infarcts might be a relatively isolated manifestation of uncontrolled acute homograft rejection. It was suggested that the hepatic blood flow, which has been shown to decline sharply in dogs at this time,${ }^{10}$ might have dropped in some regions below a life sustaining level. A similar hypothesis, based on angiographic studies in dogs, had previously been advanced by Moore et al. ${ }^{16}$ As a primary explanation, this proposition has since lost much of its persuasiveness in view of the aforementioned observations from the four autopsy examinations.

In these four homografts, including the two which were examined 2 and 8 days after thrombosis of the right lobar arterial supply, there was little or no evidence of active rejection in the uninfarcted portions of the liver. The concept that immunologically mediated reductions in blood flow should specifically effect the right portion of the organ is further weakened by the fact that this kind of selective regional vulnerability of the liver has never been reported in animal studies and probably does not occur, at least in dogs and pigs. In the canine and porcine bacteriologic experiments cited above ${ }^{3}$ and in a separate investigation of liver scanning in dogs, ${ }^{8}$ lobar and segmental necrosis were specifically looked for. There was not a single example in 32 experiments.

There is now evidence from studies in fresh cadavers that mechanical factors predispose man (or at least small children) to a right lobar vascular accident, possibly because of the erect position used by humans. In humans the right hepatic artery is longer than the left branch (Fig. 18A) and usually traverses behind the other central hilar structures where it is held by surrounding tissues. When the restraining ligaments of the liver are cut and when the vascular structures entering and leaving the liver are skeletonized, the right lobe rotates on the fulcrum of the vertebral column and recedes to a somewhat more posterior and inferior location than normal. If the head of the $\mathrm{x}$-ray table is elevated to $60^{\circ}$, a sharp kink of the proximal right hepatic artery can be demonstrated (Fig. 18B). Presumably such a dangerous situation could be further aggravated in the post-transplantation period either by the diminutions in blood flow or by the organ swelling which occurs with rejection. The constellation of circumstances might be especially hazardous in infant livers with their fine caliber thin-walled arterial branches.

Because of the possible contributory role of such mechanical factors in the production of right lobar infarction, the homograft was fixed in the desired position in the last two cases by firmly reattaching its falciform ligament to the same ligament in the recipient. Thus far, these two patients have not had any evidence of acute liver necrosis during the follow up studies of one and $2 \frac{1}{3}$ months, respectively.

Compared to the septic liver infarctions, the other complications seen in these patients seemed relatively trivial. The mild intraoperative bleeding diathesis required no therapy. The acute acidosis which occurred at about the same time ${ }^{20}$ was easily managed. The right hemidiaphragmatic paralysis which was probably caused by crushing the right phrenic nerve in Patients $1-3$, was transient ( 10 to 50 days); furthermore it was prevented in the next four cases.

Certain other complications which plagued earlier attempts at orthotopic liver 

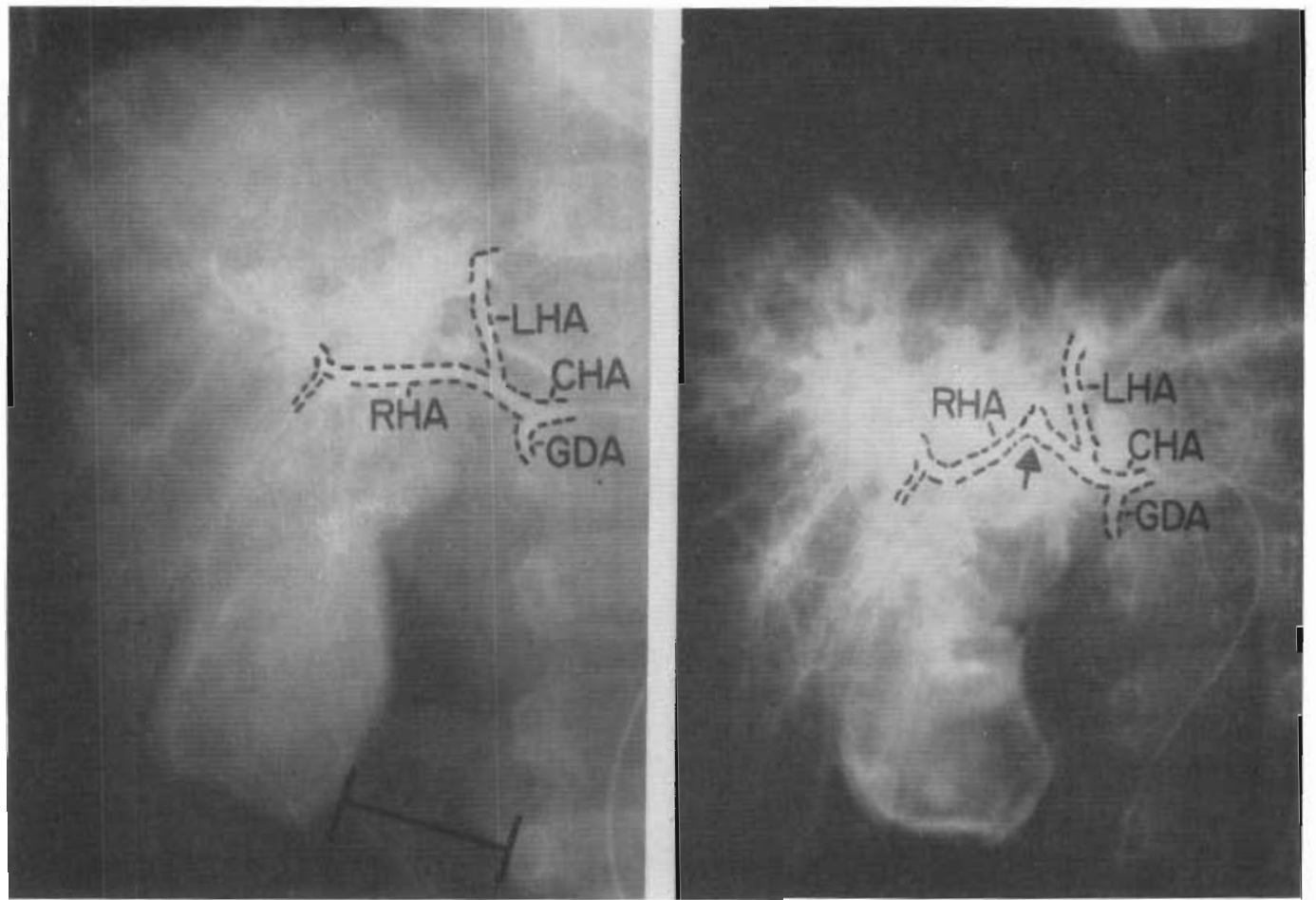

Fic. 18. Angiographic studies performed in a 5-year-old child immediately after her death from head injuries. Dye was injected into the common hepatic artery (CHA) proximal to the gastroduodenal artery (GDA). Left-Initial injection. Note the smooth course of the right hepatic artery (RHA). Right-The restraining ligaments of the liver have been incised, a cholecystoduodinostomy performed, and the head of the $x$-ray table elevated to $60^{\circ}$. The right lobe of the liver has rotated down and medially. The course of the left hepatic artery is undisturbed. However, the right hepatic artery (RHA) is now severely kinked where it passes beneath the common duct (see discussion).

transplantation were eliminated in the present series. Postoperative gastrointestinal hemorrhage did not develop in any of the patients. Pulmonary embolization, which was either the primary or an important contributory cause of death in three of the first five recipients of orthotopic liver homografts, ${ }^{22,}{ }^{23}$ did not occur at all. In the carlier cases, the clots originated at or near the lower venotomy sites used for insertion of plastic bypasses. ${ }^{23,2 \pi}$ At that time, such prostheses were thought necessary during the anhepatic phase for decompression of the blocked portal and vena caval systems. It is tragic to realize from the experience in the presently reported series that such external bypasses are not necessary.
Most importantly, the toxicity from immunosuppressive agents so often seen in our earlier experience ${ }^{19,22,23}$ was avoided. There were no examples of bone marrow depression, probably because the azathioprine doses were generally kept at less than one mg./Kg. per day. Prednisone was initially given in large quantities but reduced thereafter as rapidly as possible. Heterologous antilymphocyte globulin (ALG) which in many dogs can delay or prevent liver homograft rejection when used as the only therapy, ${ }^{2+}$ was employed as an adjuvant agent in the same general way as has been reported after clinical renal homotransplantation. ${ }^{24}$

Patients 6 and 7 in this series have had only minor and easily reversible signs of 
rejection during their one and $2 \frac{1}{2}$ month periods of follow-up study. Evaluation of the effectiveness of the foregoing immunosuppressive regimen was complicated in the other five cases by the development of extensive liver necrosis which, as discussed earlier, was not necessarily caused by rejection but which could be expected to adversely effect both hepatic function and structure. In one of the latter three patients who survived this complication at 23 days (Case 1), a liver biopsy 77 days later had only minimal abnormalities. The donorrecipient histocompatibility match in this case was the best one in the entire series; good liver function has been maintained during the entire 9 months after transplantation. The other two children who were saved by liver debridement or excision, only to die of hepatic failure 4 and $5 \frac{1}{2}$ months later, had shrunken homografts at autopsy. Histologically, these organs had the kind of fibrosis seen in many long survivors after comparable canine liver transplantation. $^{21}$ However, there were no mononuclear cells or other stigmata of active rejection in the specimens.

Similarly, the principal abnormalities in the homografts from the two children who died after 2 and $3 \frac{1}{2}$ months, within a few days after right hepatic artery thrombosis, were those of repair and to a lesser degree, regeneration. In each, the extent of fibrosis was moderate. Both of these patients had passed through difficult early rejections but had good liver function prior to the vascular accidents in the transplants; serum bilirubins were 2 and $2.3 \mathrm{mg}$. $/ 100 \mathrm{ml}$., respectively, just before death.

Reasonable conclusions from these combined clinical and pathologic observations would seem to be that the immunosuppressive regimen used did not uniformly prevent the onset of rejection; that it permitted eventual control of the acute phase of this process; and that the degree of ultimate organ damage was a reflection of the severity of earlier rejection injury and in turn of the extent of donor-recipient histocompatibility. Efforts to improve the histocompatibility matches in future trials will depend upon characterization of the white cell antigen profile of a large number of prospective recipients from whom the appropriate choice could be made. In order to have a large enough recipient pool to permit fine selectivity, an inter-city network of collaborating physicians will be necessary such as that which is now being developed through our institutions.

\section{Summary}

Seven patients aged 13 months to 16 years were treated with orthotopic homotransplantation of cadaveric livers between July, 1967 and March, 1968. The indication for operation was congenital extrahepatic biliary atresia in five cases and carcinoma of the liver in the other two. The histocompatibility match between the donors and recipients ranged from poor to excellent. After donor death, the homografts received interim preservation with a technic that included hypothermia, hyperbaric oxygenation and perfusion with diluted blood. Postoperative immunosuppressive therapy was provided with azathioprine, prednisone, and heterologous antilymphocyte globulin (ALG). Four of the recipients died after $60,105,133$, and 186 days. The other three are still alive after $9,2 \frac{1}{3}$, and one months. The improved results in the present series compared with those obtained in earlier human trials, seem to be a consequence of improved donor selection, the application of an effective organ preservation system and the use of an improved immunosuppressive regimen.

All seven of the recipients had good early liver function. In five of the seven cases all or part of the right liver lobe underwent necrosis from 2 to 104 days after operation. Thrombosis of the right hepatic artery was proved in four of these homografts either at operation or autopsy; additional angiographic studies in cadavers suggested that 
the regional de-arterialization had an at least partially mechanical etiology. With invasion of the necrotic liver tissue by gram negative bacteria, the patients became profoundly toxic. Two of the recipients died within a few days, and two others died of progressive liver failure 4 and 5\% months later.

In the 5 livers studied pathologically from 60 days to more than 6 months after transplantation, there was portal fibrosis, a slight infiltration by small lymphocytes around the portal vein branches, proliferation of small bile ductules and some central cholestasis. One of the two longer surviving homografts had progressed to cirrhosis and in both many of the small hepatic artery branches were narrowed by intimal thickening. These various changes are thought to be the result of rejections; they were least severe in the homograft which was shown by lymphocyte typing to be most compatible with its recipient.

\section{Addendum}

July 13, 1968-The 3 patients surviving at the time the manuscript was submitted are still alive. The first patient will be one year post-transplantation in 10 days. The other 2 have now been followed for 5 and 4 postoperative months respectively. Three other recipients treated 3 months, 6 weeks, and 31/2 weeks ago are well. There have been no septic hepatic infarctions in the last 5 cases.

\section{References}

1. Alican, F. and Hardy, J. D.: Replantation of the Liver in Dogs. J. Surg. Res., 7:368, 1967.

2. Brettschneider, L., Daloze, P. M., Huguet, C., Porter, K. A., Groth, C. G., Kashiwagi, N., Hutchison, D. E. and Starzl, T. E.: The Use of Combined Preservation Techniques for Extended Storage of Orthotopic Liver Homografts. Surg. Gynec. Obstet., 126:263, 1968.

3. Brettschneider, L., Tong, I. L., Boose, D. S., Daloze, P. M., Smith, G. V., Huguet, C., Blanchard, H., Groth, C. G. and Starzl, T. E.: Specific Bacteriologic Problems with Canine Orthotopic Liver Transplantation. Arch. Surg., in press.

4. Dausset, J. and Rapaport, F. T.: The Hu-1 System of Human Histocompatibility. In Human Transplantation (Eds. F. T. Rapaport and J. Dausset) Grune and Stratton, New York, 1968, p. 369.
5. Demirleau, Nourreddine, Vignes, Prawerman, Reiziciner, Larraud and Louvier: Tentative d'homogreffe hepatique. Mem. Acad. Chir. (Paris), 90:177, 1964.

6. Faris, T. D., Marchioro, T. L., Hermann, T. J., Taylor, P. D. and Starzl, T. E.: Late Function of the Orthotopic Liver Homograft. S. Forum, 16:222, 1965.

7. Fonkalsrud, E. W.: Personal communication, February, 1968.

8. Groth, C. G., Brown, D. V., Cleaveland, J. D., Cordes, D. J., Brettschneider, L. and Starzl, T. E.: Radioisotope Scanning in Experimental and Clinical Orthotopic Liver Transplantation. Surg. Gynec. Obstet., in

9. Groth, C. G., Pechet, L., and Starzl, T. E.: Coagulation and Fibrinolysis in Human Orthotopic Liver Transplantation. Arch. Surg. In press.

10. Groth, C. G., Porter, K. A., Otte, J. B., Daloze, P. M., Marchioro, T. L., Brettschneider, L. and Starzl, T. E.: Studies of Blood Flow and Ultrastructural Changes in Rejecting and Non-rejecting Canine Orthotopic Liver Homografts. Surgery, 36:658, 1968.

11. Hutchison, D. E., Genton, E., Porter, K. A., Daloze, P. M., Huguet, C., Brettschneider, L., Groth, C. G. and Starzl, T. E.: Platelet Changes Following Clinical and Experimental Hepatic Homotransplantation. Arch. Surg., in press.

12. Kashiwagi, N., Brantigan, C. O., Brettschneider, L., Groth, C. G. and Starzl, T. E.: Clinical reactions and Serologic Changes Following the Administration of Heterologous Antilymphocyte Globulin to Human Recipients of Renal Homografts. Ann. Int. Med., 68:275, 1968.

13. Kashiwagi, N., Groth, C. G. and Starzl, T. E.: Changes in Serum Haptoglobin and Group Specific Component After Orthotopic Liver Transplantation in Humans. Proc. Soc. Exp. Biol. Med., in press.

14. Krovetz, L. J.: Congenital Biliary Atresia. I. Analysis of 30 Cases with Particular Reference to Diagnosis. Surgery, 47:453, 1960.

15. Marchioro, T. L., Huntley, R. T., Waddell, W. R. and Starzl, T. E.: The Use of Extracorporeal Perfusion for Obtaining Postmortem Grafts. Surgery, 54:900, 1963.

16. Moore, F. D., Birtch, A. G., Dagher, F., Veith, F., Krisher, J. A., Order, S. E., Shucart, W. A., Dammin, G.' J. and Couch, N. P.: Immunosuppression and Vascular Insufficiency in Liver Transplantation. Ann. N.Y. Acad. Sci., 120:729, 1964.

17. Peacock, J. H. and Terblanche, J.: Orthotopic Homotransplantation of the Liver in the Pig. In The Liver (Ed. A. E. Read), Butterworth, London, 1967, p. 333.

18. Sass-Kortsak, A., Macdougall, L. G., Ghanihi, H., Cherniak, M .M.: Differential Diagnosis of Regurgitation Jaundice in Early Infancy. Ann. N.Y. Acad. Sci., 111:422, 1963.

19. Starzl, T. E., Brettschneider, L. and Groth, C. G.: Recent Developments in Liver Transplantation. In Advance in Transplantation (Eds. J. Dausett, J. Hamburger, and G. Mathe ) Munksgaard Ltd., Copenhagen, 1968, pp. 633-637. 
20. Starzl, T. E., Groth, C. G. Brettschneider, L. Moon, J. B., Fulginiti, V. A., Cotton, E. K. and Porter, K. A.: Extended survival in 3 cases of Orthotopic Homotransplantation of the Human Liver. Surgery, 63:549, 1968.

21. Starzl, T. E., Marchioro, T. L., Porter, K. A., Taylor, P. D., Faris, T. D., Herrmann, T. J., Hlad, C. J. and Waddell, W. R.: Factors Determining Short- and Long-Term Survival after Orthotopic Liver Homotransplantation in the Dog. Surgery, 58:131, 1965.

22. Starzl, T. E., Marchioro, T. L., von Kaulla, K. Hermann, G., Brittain, R. S. and Waddell, W. R.: Homotransplantation of the Liver in Humans. Surg. Gynec. Obstet., 117:659, 1963.

23. Starzl, T. E., Marchioro, T. L., Rowlands, D. T., Jr., Kirkpatrick, G. H., Wilson, W. E. C. Rifkind, D. and Waddell, W. R.: Immunosuppression after Experimental and Clinical Homotransplantation of the Liver. Ann. Surg., 160:411, 1964
24. Starzl, T. E., Marchioro, T. L., Porter, K. A. Iwasaki, Y. and Cerilli, G. J.: The Use of Heterologous Antilymphoid Agents in Canine Renal and Liver Homotransplantation, and in Human Renal Homotransplantation. Surg. Gynec. Obstet., 124:301, 1967.

25. Stuart, F. P., Torres, E., Hester, W. J., Dammin, G. J. and Moore, F. D.: Orthotopic Autotransplantation and Allotransplantation of the Liver: Functional and Structural Patterns in the Dog. Ann. Surg., 165:325, 1967.

26. Terasaki, P. I., Vredevoe, D. L. and Mickey, M. R.: Serotyping for Homotransplantation. X. Survival of 196 Grafted Kidneys Subsequent to Typing. Transplantation, 5:1057, 1967.

27. von Kaulla, K. N., Kaye, H., von Kaulla, E., Marchioro, T. L. and Starzl, T. E.: Changes in Blood Coagulation Before and After $\mathrm{He}$ patectomy or Transplantation in Dogs and Man. Arch. Surg., 92:71, 1966.

\section{Discussion}

Dr. Francis D. Moore (Boston): Dr. Starzl's work in this field is absolutely outstanding and for those of us interested in liver transplantation, this is a banner day when we can contemplate four patients alive and well with lethal liver disease removed and a new liver in place. This is a magnificent achievement and liver surgery as of this day has an entirely new look from hither forward. But I would like to use this opportunity to discuss another aspect of Dr. Starzl's work.

Four years ago, at the Society of University Surgeons, when Dr. Starzl's initial clinical experience and ours likewise had ended with fatality, it was clear (and so stated at the meeting) that more progress was needed before it would be ethically, morally, surgically and scientifically acceptable to move ahead again with clinical liver transplantation.

Immunosuppression without hepatotoxicity was essential, as well as improved perfusion-storage. Now these things have come to pass, especially by the development of anti-lymphocyte globulin, and it is appropriate again to move ahead. If this forward motion is undertaken by persons or departments that have practical capability in transplant immunology and histocompatibility matching, as well as surgical experience with transplantation and the postoperative care of patients on immunosuppression, there is no need for consultant boards to declare the patient operable or a team from another institution to decide that the donor is dead.

The time-temperature curves for liver donation, the permissible normothermic dead-time, and the prior state of death are the same for liver donation as for heart, with the heart somewhat less vulnerable to normothermic ischemia.
There has recently been a statement issued by a committee in Washington that attempts to deal with these matters as applied to the heart. As nearly as I can see, none of the authors of this document has busied himself with the transplant problem over these last 15 years; the document makes no reference whatsoever to the long work of many Departments in this country who have labored through the difficult years of transplantation, nor does it acknowledge the obvious fact that actual experience in immunogenetics, immunosuppression and surgical transplantation are the essential normal prerequisites to moving ahead with any newly transplantable organ.

Nor does it make reference to the fact that the moral security of the next 25 years of American surgery, in exploring this new field, will rest secure just where it has in the past 20 years: in giving free and untrammelled opportunity for development to those Departments and individuals that are willing to take the time and trouble to develop both the immunological and surgical aspects of organ transplantation, as Dr. Starzl has demonstrated today with a project that was held in abeyance until the fundamentally ethical nature of science itself indicated that it was time again to move ahead

Dr. Eric W. Fonkalsrud (Los Angeles): I would like to congratulate Dr. Starzl and his associates for their very excellent contributions to furthering the knowledge of both liver preservation and transplantation, and for their remarkably good clinical results, shown in this study.

We have followed Dr. Starzl's work with very great interest, however have used a slightly different technic in the laboratory and in one patient. 
The emphasis in our studies has been on the use of hepatic cell stabilizing drugs, such as chlorpromazine and cortisone administered to the donor after death followed by external hypthermia to the graft after excision. A siliconized internal vascular shunt has been used to decompress the inferior vena cava and portal vein to the right atrium in the recipient.

This slide [slide] shows the liver of a $2 \frac{1}{2} 2_{\text {-year- }}$ old boy with biliary atresis who underwent orthotopic liver transplantation. The total time of liver ischemia was 91 minutes.

This photograph shows how pink and uncongested the graft appeared 30 minutes after revascularization. The falciform ligament and suspensory ligaments of the grate were attached to the diaphragm in this patient, not so much to prevent arterial kinking as to provide support to the vena caval anastomosis.

The patient recovered from the operation rapidly and experienced a drop in bilirubin from 33 to $4.5 \mathrm{mg}$. $/ 100 \mathrm{ml}$. and alkaline phosphatase from 115 to $15 \mathrm{KA}$ units within 24 hours. There was prompt good bile excretion which was drained externally. Immunosuppression was started on the day of operation and continued as in Dr. Starzl's study.

The patient was ambulatory and taking a regular diet when, on the fourteenth day, he promptly became septic-and developed air under the right diaphragm as is shown on this abdominal roentgenogram. Exploration showed a large area of necrosis in the dome of the right lobe of the liver, as is shown on this slide. Postmortem showed thrombosis of the small branches of the right hepatic artery, as is seen in this photograph, and which is very similar to those described in Dr. Starzl's paper today. All of the major vascular anastomoses were patent.

This photomicrograph shows an area of relatively normal liver tissue with ductal proliferation in the area that was not infarcted. The area of transition between the infarct and the normal liver tissue is clearly seen. I would like to ask Dr. Starzl if he has an explanation for why arterial thrombosis occurs so late after grafting and if he believes there may be additional causative factors such as a manifestation of rejection? Do you believe that adding arterial blood to the portal vein may be of any benefit in these patients? Would short- or long-term anticoagulation be of any help?

Dr. Thomas E. Starzl (Closing): I would like to thank Dr. Moore not only for the thoughts he expressed, but for the kindness he has displayed to us this afternoon and at all times in the past, which has made it possible for our two institutions to exchange data long before it was published.

The approach to preservation described by Dr. Fonkalsrud is a different one than we used in our cases. We were anxious to obtain longer term preservation than we have ever found possible with such simple perfusion methods. With our recently used technic we have been able to see the liver within the chamber and to evaluate it under circumstances of perfusion before anvthing was done to the recipient.

As to the cause for the late thrombosis, I think one can only speculate. It seems likely to us that the mechanical defect which I demonstrated earlier may not be completely occlusive and that there may be added factors, as Dr. Fonkalsrud suggested. Possibilities might include the swelling that occurs in liver homografts at the time of active rejection, or alternatively the diminished blood flow that is very often seen in the canine liver at the time of a potentially reversible rejection. With a combination of any of these circumstances, infant livers with their fragile arteries might be subject to a special risk of dearterialization. 